\title{
The Mineral and Aqueous Phase Evolution of Sulfur and Nickel with Weathering of Pyrrhotite in a Low Sulfide, Granitic Waste Rock
}

Jeff B. Langman ${ }^{\mathrm{a}, \mathrm{b}}$, David W. Blowes ${ }^{\mathrm{b}}$, Harish Veeramani ${ }^{\mathrm{b}}$, David Wilson ${ }^{\mathrm{b}}$, Leslie Smith $^{\mathrm{c}}$, David C. Sego ${ }^{\mathrm{d}}$, and Dogan Paktunc ${ }^{\mathrm{e}}$

${ }^{a}$ University of Idaho, Department of Geological Sciences, Moscow, ID, USA

${ }^{b}$ University of Waterloo, Department of Earth and Environmental Sciences, Waterloo, ON, Canada

${ }^{c}$ Department of Earth and Ocean Sciences, University of British Columbia, Vancouver, BC, Canada

${ }^{d}$ Department of Civil and Environmental Engineering, University of Alberta, Edmonton, AB, Canada

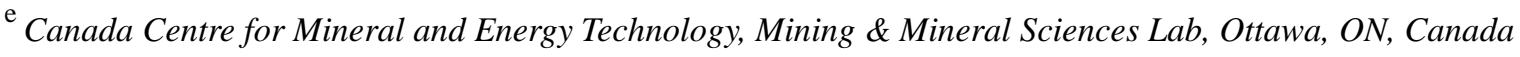

Corresponding author: Jeff Langman, jlangman@uidaho.edu

\section{ABSTRACT}

The release of $\mathrm{S}$ and metals from the weathering of waste rock pyrrhotite $\left[\mathrm{Fe}_{(1-\mathrm{x})} \mathrm{S}\right]$ is affected by oxidation pathways, the presence and concentration of Fe-substitution metals (e.g. Ni), and Fe (oxyhydr)oxide products. A 4C (monoclinic) pyrrhotite [ $\mathrm{Fe}_{7} \mathrm{~S}_{8}, \mathrm{Ni}$ :Fe substitution of about 1:200] in a low sulfide waste rock was weathered in the laboratory and at a field site to identify the evolution of $\mathrm{S}$ oxidation, distribution and coordination of $\mathrm{Ni}$, and possible adsorption of $\mathrm{Ni}$ on secondary Fe minerals. Mineral phase $\mathrm{S}$ was present in the $-2,-1,0,+4$, and +6 oxidation states prior to its release as $\mathrm{SO}_{4}{ }^{2-}$ into solution. The thiosulfate $\left[\mathrm{S}_{2} \mathrm{O}_{3}{ }^{2-}\right]$ pathway of sulfide oxidation was indicated by the presence of polythionates and $\mathrm{S}_{2} \mathrm{O}_{3}{ }^{2-}$. Sulfur as $\mathrm{S}_{2} \mathrm{O}_{3}{ }^{2-}$ was more persistent than sulfite $\left[\mathrm{SO}_{3}{ }^{2-}\right]$ prior to oxidation to $\mathrm{SO}_{4}{ }^{2-}$. The release of $\mathrm{Ni}$ during the oxidative dissolution of pyrrhotite was influenced by its distribution in the grain: diffuse throughout the grain (solid solution mineral) or concentrated in exsolved pentlandite $\left[(\mathrm{Fe}, \mathrm{Ni})_{9} \mathrm{~S}_{8}\right]$ lamellae within the pyrrhotite. With the oxidation of S, Ni coordination changed from bonding with reduced S species to bonding with oxygen prior to its release with $\mathrm{SO}_{4}{ }^{2-}$. Sulfur as $\mathrm{SO}_{4}{ }^{2-}$ typically stayed in solution with release from the pyrrhotite, but the solubility of released Ni was dependent on leachate $\mathrm{pH}$. A 
near-neutral $\mathrm{pH}$ induced the adsorption of $\mathrm{Ni}$ onto $\mathrm{Fe}$ (oxyhydr)oxides, which formed during oxidation of the pyrrhotite. In some grains, Ni was found concentrated in Fe distal precipitates as opposed to the closer alteration layers/zones of the sulfide grain. Subsequent dissolution of the Fe (oxyhydr)oxides or desorption of $\mathrm{Ni}$ with a change in $\mathrm{pH}$ provides a delayed release of $\mathrm{Ni}$ into solution. This improved understanding of the oxidation pathway of S, coordination and release of $\mathrm{Ni}$, and influence of $\mathrm{Fe}$ (oxyhydr)oxides in the weathering of pyrrhotite will assist in determining appropriate reaction-rate factors and element release rates for prediction of acid rock drainage.

Keywords: pyrrhotite weathering, sulfur oxidation, nickel coordination, nickel adsorption, shrinking core model

\section{Introduction}

Weathering of waste rock proceeds rapidly by partial oxidation of sulfide minerals, but further oxidative dissolution may be constrained by the availability of oxygen to sustain oxidation and water for hydrolysis and leaching of elements into solution (Nordstrom and Southam, 1997; Nordstrom and Alpers, 1999; Blowes et al., 2003). The variable element composition, crystal structure, and substitution metals associated with pyrrhotite $\left[\mathrm{Fe}_{(1-\mathrm{x})} \mathrm{S}\right]$ also affect its rate of weathering (Belzile et al., 2004; Chen et al., 2006; Janzen et al., 2000; Orlova et al., 1989; Yakhontova et al., 1983). Pyrrhotite occurs in various crystal structures (polytypes) that differ according to the level of Fe vacancy (Becker et al., 1997; de Villiers and Liles, 2010; de Villiers et al., 2009; Elliot, 2010; Wang and Salveson, 2005). Differences in Fe vacancies produce nonstoichiometric composition, multiple crystal systems (monoclinic, hexagonal, or orthorhombic), and metal substitutions, such as the inclusion of Co and Ni (Harries et al., 2013; 
Janzen et al., 2000; Orlova et al., 1989; Pósfai et al., 2000). A low sulfide, granitic waste rock containing a common Fe-deficient pyrrhotite $\left(\mathrm{Fe}_{7} \mathrm{~S}_{8}\right.$ or $4 \mathrm{C}$ (monoclinic) pyrrhotite) that included traces of $\mathrm{Ni}$ and $\mathrm{Co}\left[\left(\mathrm{Fe}_{0.852} \mathrm{Ni}_{0.004} \mathrm{Co}_{0.001}\right)_{\Sigma 0.857} \mathrm{~S}\right]$ was weathered during laboratory and field experiments. The objectives of these experiments were to examine the formation of weathering products and observe the evolution of the oxidation, retention, and release of $\mathrm{S}$ and $\mathrm{Ni}$. A better understanding of the oxidation state and coordination of $\mathrm{S}$ and $\mathrm{Ni}$ in the pyrrhotite grains will assist in determining appropriate reaction-rate factors and element release rates for prediction of acid rock drainage (ARD).

The weathering of pyrrhotite commonly produces secondary oxidation products that form alteration layers (or discontinuous zones) of $\mathrm{Fe}_{7} \mathrm{~S}_{8}+\mathrm{Fe}_{2} \mathrm{~S}_{3}, \mathrm{FeS}_{2}$, and $\mathrm{Fe}$ (oxyhydr)oxides, where $\mathrm{S}$ is not expected to migrate from the $\mathrm{FeS}_{2}$ (marcasite or enriched $\mathrm{S}$ layer) to the outer ferric Fe layer (Mycroft et al., 1995; Cruz et al., 2005). Under oxidative conditions, the formation of Fe (oxyhydr)oxides provides an external barrier to pyrrhotite dissolution (Mycroft et al., 1995; Thomas et al., 1998, 2001). The loss of S (Eq. 1) and retention of Fe (Eqs. 2 and 3) in the weathered layers can produce various Fe (oxyhydr)oxides, such as goethite $[\alpha-\mathrm{FeO}(\mathrm{OH})]$, lepidocrocite $[\gamma-\mathrm{FeO}(\mathrm{OH})]$, magnetite $\left[\mathrm{Fe}^{2+} \mathrm{Fe}^{3+}{ }_{2} \mathrm{O}_{4}\right]$, ferrihydrite $\left[\mathrm{Fe}_{2} \mathrm{O}_{3} \cdot 0.5 \mathrm{H}_{2} \mathrm{O}\right]$, and hematite $\left[\mathrm{Fe}_{2} \mathrm{O}_{3}\right]$. The oxidative dissolution of pyrrhotite produces greater $\mathrm{S}$ release early in the weathering process followed by the potential for greater release of Fe with dissolution of the alteration layers (Thomas et al., 1998). The different element release periods create a variable end product depending on $\mathrm{pH}$ and the extent of oxidation and dissolution (Eq. 2).

$$
\begin{aligned}
& \mathrm{Fe}_{(1-x)} \mathrm{S}+(2-(1 / 2) x) \mathrm{O}_{2}+x \mathrm{H}_{2} \mathrm{O}=>(1-x) \mathrm{Fe}^{2+}+\mathrm{SO}_{4}{ }^{2-}+2 x \mathrm{H}^{+} \\
& \mathrm{Fe}_{(1-x)} \mathrm{S}+\mathrm{O}_{2}+\mathrm{H}_{2} \mathrm{O}=>\mathrm{Fe}_{2} \mathrm{O}_{3} \cdot \mathrm{H}_{2} \mathrm{O} \text { and/or } \mathrm{FeOOH} \text { and/or Fey } \mathrm{S}_{\mathrm{z}} \text { (unbalanced) } \\
& 4 \mathrm{Fe}^{2+}+\mathrm{O}_{2}+10 \mathrm{H}_{2} \mathrm{O}=>4 \mathrm{Fe}(\mathrm{OH})_{3}(\mathrm{~s})+8 \mathrm{H}^{+}
\end{aligned}
$$


The alteration layers of oxidized pyrrhotite can be composed of various Fe-deficient sulfides, polysulfides, elemental S, and sulfooxyanions as stable or metastable intermediaries along with $\mathrm{SO}_{4}{ }^{2-}$ and $\mathrm{Fe}$ (oxyhydr)oxide products (Belzile et al., 2004; Blowes and Jambor, 1990; Buckley and Woods, 1985; Davis and Ritchie, 1986; Kalinkin et al., 2000; Mikhlin et al., 2002; Plysunin et al., 1990; Steger and Desjardins, 1977, 1978). The evolution of the pyrrhotite reaction rate and development of the alteration layers can be described conceptually and mathematically by the shrinking core concept (Cathles, 1979; Davis and Ritchie, 1986, 1987; Davis et al., 1986; Levenspiel, 1972; Mayer et al., 2002; Wunderly et al., 1996), but accurate modeling of ARD using this concept requires adjustments to modeling variables to account for the variability in crystal structure, heterogeneity of secondary mineral formation, and presence and behavior of substitution metals.

The point at which $\mathrm{Ni}$ is released during pyrrhotite weathering is not well constrained but represents a potential weathering indicator because of its greater solubility in near-neutral $\mathrm{pH}$ compared to Fe. Nickel substitutes for Fe in pyrrhotite at trace levels (Arnold, 1966; Janzen et al., 2000), but it may be unevenly distributed. Within pyrrhotite, Ni can be diffusely distributed as a common Fe substitute or in discontinuous layers or fine lamellae (basal parting) of pentlandite $\left[(\mathrm{Fe}, \mathrm{Ni})_{9} \mathrm{~S}_{8}\right]$ (Janzen, 1996; Naldrett et al., 1967). Pentlandite likely forms during exsolution of a nickeliferous pyrrhotite, which produces concentrated $\mathrm{Ni}$ in pentlandite lamellae with lower $\mathrm{Ni}$ abundance distributed throughout the pyrrhotite grain (Etschmann et al., 2004; Hawley, 1962; Naldrett et al., 1967). The release of $\mathrm{Ni}$ into solution from oxidative dissolution of pyrrhotite is primarily dependent upon the local $\mathrm{pH}$, which controls the mobility of trace metals such as $\mathrm{Ni}$ (Nordstrom, 2011); however, the release of Ni may be influenced by its distribution within the pyrrhotite (diffusely distributed or as pentlandite lamellae) and the presence of various $\mathrm{Fe}$ (oxyhydr)oxides in the alteration zones. 


\subsection{Mine site and waste rock}

Samples of a low sulfide waste rock containing pyrrhotite were collected from the Diavik Diamond Mine (Diavik), located on an island in Lac de Gras in the Northwest Territories, Canada (Fig. 1), as part of the Diavik Waste Rock Project. The site is in the Canadian Arctic: a permafrost, polar climate area with an annual precipitation of less than $300 \mathrm{~mm}$ (40\% as rain, $60 \%$ as snow) and average minimum, mean, and maximum temperatures of $-31,-9$, and $18{ }^{\circ} \mathrm{C}$, respectively (Environment Canada, 2013). An active freeze-thaw zone extends $4 \mathrm{~m}$ into the bedrock at the site, and deeper into unconsolidated materials (Pham et al., 2013). The waste rock is composed of about $75 \%$ granite, $14 \%$ pegmatitic granite (pegmatite), $10 \%$ biotite schist, and $1 \%$ diabase (Blowes and Logsdon, 1998). The granites are primarily quartz $\left[\mathrm{SiO}_{2}\right], \mathrm{K}$-feldspar $\left[\mathrm{KAlSi}_{3} \mathrm{O}_{8}\right]$, and albite $\left[\mathrm{NaAlSi}_{3} \mathrm{O}_{8}\right]$, with greater albite in the granite and greater $\mathrm{K}$-feldspar in the pegmatite (Jambor, 1997). The biotite schist is composed primarily of albite (35-55\%), quartz (20-50\%), and biotite $\left[\mathrm{K}(\mathrm{Mg}, \mathrm{Fe})_{3} \mathrm{AlSi}_{3} \mathrm{O}_{10}(\mathrm{OH})_{2}\right](10-25 \%)$ and has a mean sulfide content of 0.24 wt. \% S (range of 0.02 to $0.42 \mathrm{wt}$ \% S). The sulfide in the schist is primarily composed of pyrrhotite ranging from 50 to $200 \mu \mathrm{m}$ in diameter (Jambor, 1997).

Fig. 1. The Diavik Diamond Mine is located on East Island in Lac de Gras-300 km northeast of Yellowknife, NT, $220 \mathrm{~km}$ south of the Arctic Circle_-and is the location of the Diavik Waste Rock Project (Smith et al., 2013c; photo courtesy of Diavik Diamond Mines, Inc.).

\section{Materials and methods}

Waste rock was collected for weathering under laboratory conditions (humidity cell) and to construct field-site, experimental, waste-rock piles (test piles) to examine weathering under natural conditions as part of the Diavik Waste Rock Project. The humidity cell experiment is described in Langman et al. (2014), and the construction of the two test piles (about 32,000 $\mathrm{m}^{3}$ each) in 2006 , weathering conditions, and leachate generation are described by Neuner et al. (2013), Pham et al. (2013), Sinclair (2014), and Smith et al. (2013a,b,c). Laboratory samples (1 kg, screened to <6.3 $\mathrm{mm}$ ) were segregated according to sulfur content (range of 0.02-0.18 wt. \%) and separated at 0.04 
and 0.08 wt. \% for relative low, moderate, and high S content (or Type I, II, and III waste rock designations used at the mine site). The segregated samples were placed in humidity cells in 2005 for weathering according to ASTM D5744 (ASTM, 2013). Post-weathering samples were collected during deconstruction of the humidity cells in 2013. Weathered field samples were collected as bulk samples from the active zone (upper surface layer or 0-2 $\mathrm{m}$ depth) of the test piles in 2011 and during borehole drilling at the center of each test pile in 2013. These samples represent a range of S content similar to the rock used for the laboratory experiment, and the field samples experienced different weathering environments depending on location in the test piles (active zone compared to lower zones). Additionally, unweathered samples collected for the humidity cell experiment were stored for comparison to the subsequently weathered samples. For individual mineral characterization, all rock samples were freeze dried and subsampled for thin sections: non-aqueous epoxy, double polished to $60-\mu \mathrm{m}$ thickness, placed on glass slides, and gold coated for charge dispersion during electron microscope imaging and protection of the mineral surface.

Bulk pyrrhotite (multiple grains separated from the waste rock) from humidity cell and testpile samples were analyzed for S species using synchrotron x-ray absorption spectroscopy (XAS) at the 06B1-1 beamline (SXRMB) at the Canadian Light Source (CLS), Saskatchewan, Canada. The pyrrhotite grains were magnetically separated from the waste rock, then powdered and stored in an anoxic environment to minimize oxidation of the fresh surfaces. Beamline 06B1-1 uses a $\mathrm{Si}(111)$ monochromator to deliver an incident beam energy of $1.7-10 \mathrm{keV}$, which is suitable for resolving $\mathrm{S}(2.472 \mathrm{keV})$ spectra. A broad beam measuring about $3 \times 2 \mathrm{~mm}$ was used for collection of $\mathrm{x}$-ray fluorescence (XRF) spectra for x-ray absorption near edge structure (XANES) analysis of the bulk pyrrhotite samples. The spectra were processed with the XAS program ATHENA (Ravel and Newville, 2005).

The alteration layers of selected pyrrhotite grains from the humidity cells and test piles were investigated using optical microscopy (Nikon Eclipse LV100N-POL) and scanning electron 
microscopy with energy dispersive spectrometry (SEM-EDS; Hitachi TM 3000) at the University of Waterloo. The speciation and coordination of $\mathrm{S}$ and $\mathrm{Ni}$ at discrete locations on pyrrhotite grains were examined using XAS at beamline 13 ID-E (microprobe), GESCARS, Advanced Photon Source (APS) at Argonne National Laboratory in Argonne, Illinois, USA. Beamline 13-ID-E uses a $\mathrm{Si}(111)$ monochromator to deliver an incident beam energy of 2.4-28 keV, which is suitable for resolving S and Ni (8.333 keV). Data acquisition utilized a four-element, Hitachi Vortex, silicondrift detector and a focused beam measuring $2 \times 2 \mu \mathrm{m}$. At APS, $\mu$-XRF maps were produced to examine element distributions across pyrrhotite grains and identify locations for acquisition of $\mathrm{S}$ and Ni XANES spectra. Sulfur and Ni K-edge energies for reference materials at CLS and APS were determined as the maxima of the first derivative for the absorption spectra and were shifted to theoretical values of 2.472 and $8.333 \mathrm{keV}$, respectively, to account for beamline flux.

Iron oxidation products in weathered alteration zones of the selected pyrrhotite grains were analyzed using micro x-ray diffraction $(\mu-X R D)$ at the Canada Centre for Mineral and Energy Technology (CANMET) in Ottawa, Canada. The $\mu$-XRD analyses were performed using a Rigaku MicroMax-007HF with a 50- $\mu \mathrm{m}$ collimator, and the diffractograms were interpreted with JADE (Materials Data, Inc.). Phase identification was based on the number of identifiable peaks: 5 peaks or greater for high confidence and 3-4 peaks for low confidence. Results of pyrrhotite analyses are discussed relative to the "grain system" composed of the pyrrhotite, weathered layers containing various $\mathrm{S}$ and $\mathrm{Fe}$ mineral phases, and surrounding precipitated mineral phases (distal Fe precipitates) of the weathered grain.

\section{Results and discussion}

\subsection{The relation of $S$ and $\mathrm{Ni}$ in waste rock leachate}

The solute and $\mathrm{pH}$ relations in leachate from the humidity cell and test pile experiments in the Diavik Waste Rock Project has been characterized by Langman et al. (2014), Sinclair (2014), and Smith et al. (2013a,b), and a relation between $\mathrm{SO}_{4}{ }^{2-}$ and $\mathrm{Ni}$ (and $\mathrm{Co}$ ) in acidic leachate (median $\mathrm{pH}$ 
of 4.6 for the humidity cell and test-pile leachates) has been observed (Fig. 2). Nickel hydroxide $\left[\mathrm{Ni}(\mathrm{OH})_{2}\right]$ is a common control for $\mathrm{Ni}$ in ARD (Alpers et al., 1994), but leachate from the humidity cells and test piles was consistently undersaturated for this phase (Sinclair, 2014; Smith et al., 2013a). Additionally, the adsorption of $\mathrm{Ni}$ on Fe (oxyhydr)oxides can retard the release of Ni into solution (Boujelben and Elouear, 2009; Cornell, 1991; Galan et al., 2003; Gunsinger et al., 2006; Lee et al., 2002). The strong correlation of $\mathrm{Ni}$ and $\mathrm{SO}_{4}{ }^{2-}$ in acidic leachate (Fig. 2) suggests the release of $\mathrm{Ni}$ with oxidation and release of $\mathrm{S}$ and a lack of $\mathrm{Ni}$ adsorption under these acidic conditions. Nickel and Fe had a weak correlation under all leachate conditions. This lack of Ni:Fe correlation was expected because of the $>\mathrm{pH} 4$ of the acidic leachates and lower solubility of $\mathrm{Fe}^{3+}$ in oxic solutions >pH 4 (Appelo and Postma, 2005).

Sulfate acts conservatively in acidic or near-neutral solutions that are undersaturated with respect to gypsum $\left[\mathrm{CaSO}_{4} \cdot 2 \mathrm{H}_{2} \mathrm{O}\right]$ and jarosite $\left[\mathrm{KFe}_{3}(\mathrm{OH})_{6}\left(\mathrm{SO}_{4}\right)_{2}\right]$ (Nordstrom, 2011). Nickel solubility will increase below near-neutral pH, particularly less than 5.5 (Stumm, 1992; Theis and Richter, 1980). Under acidic conditions, a strong correlation of $\mathrm{SO}_{4}{ }^{2-}$ and $\mathrm{Ni}$ (and Co) was observed for leachate from the humidity cells and the test piles, but this correlation weakened under near-neutral conditions (Fig. 2). A statistical examination of the $\mathrm{SO}_{4}{ }^{2-}$ to $\mathrm{Ni}$ relation (Spearman's rank correlation coefficient) indicated the correlation was slightly stronger under more acidic field conditions $(\rho=0.81)$ than under near-neutral field conditions $(\rho=0.77)$. The correlation was weaker at the humidity cell scale (Fig. 2), but the humidity cells that produced acidic leachate had a significantly stronger correlation $(\rho=0.72)$ than the humidity cells with nearneutral leachate $(\rho=0.30)$.

Fig. 2. Trends in concentrations of $\mathrm{Co}, \mathrm{Ni}$, and $\mathrm{SO}_{4}{ }^{2-}$ (Savitzky-Golay Method; Savitzky and Golay, 1964) in leachate from humidity cells and experimental waste rock piles that were constructed as part of the Diavik Waste Rock Project. Broken trendlines are where the relation cannot be described using the Savitzky-Golay Method (high variability and weak correlation). The humidity cell experiment was on a weekly flushing schedule, and active days for the experimental piles were days that flow was observed in the basal drains.

\subsection{Pyrrhotite weathering, element distribution, and alteration intensity}

Pyrrhotite grains in variously weathered states were identified in the humidity cell and test pile 
samples (Fig. 3). Some of the grains are fractured, likely due to blasting during mining, which enhances weathering because of the larger reactive surface areas. Completely unweathered pyrrhotite has not been collected because the mining and waste-disposal process provides an initial oxidation period. Examples of minimally-weathered pyrrhotite from the experiments are shown in Figure $3 \mathrm{a}$ and e. Indicators of greater weathering are visible as formation of Fe (oxyhydr)oxide minerals within fractures and as alteration layers/zones (present in all examples shown in Fig. 3), distal Fe precipitates (Fig. 3c-e), and etching of the sulfide mineral surface (distinctly visible in Fig. 3f). The intensity of sulfide alteration can be described by the sulfide alteration index (SAI; Blowes and Jambor, 1990), where a rating of zero would indicate no oxidation and a rating of ten would indicate complete obliteration of the pyrrhotite. Examples presented in Fig. 3 represent SAIs of 2-3 (minimally weathered, Fig. 3a and e) to 10 (well weathered (Fig. 3h) or only Fe (oxyhydr)oxide(s) and no remaining pyrrhotite).

The effect of weathering on the $\mathrm{S}: F e$ relation is visible in the $\mathrm{S}$ and Fe distribution maps from $\mu$-XRF analysis (Figs. 4 and 5). An example of a minimally-weathered pyrrhotite (Figs. 4a and 5a) represents the sulfide-rich state $\left(\mathrm{Fe}_{7} \mathrm{~S}_{8}+\mathrm{Fe}_{2} \mathrm{~S}_{3}\right.$ or marcasite state) due to Fe transport through the porous S layer and the likely decrease in S-S bond length (Fleet, 1978; Fowler and Crundwell, 1999). Further oxidation reduces the abundance of $\mathrm{S}$, producing grains that are Fe-rich (Figs. $4 \mathrm{~b}-\mathrm{g}$ and $5 \mathrm{~b}$; various levels of Fe richness) and the possible loss of all $\mathrm{S}$ because of continued oxidation (Fig. 4h). Retention of the Fe within the grain (Fig. 4f) through formation of alteration layers (Figs. 4d and 5c) or distal precipitates (Fig. 4b,e,g) depends on the local solution $\mathrm{pH}$ and the rate of dissolution of the Fe mineral phases (Stumm, 1992). The release of Fe from the grain and formation of distal Fe precipitates are influenced by encapsulating minerals, such as biotite (Fig. 4b), which can restrict weathering processes along the isolated grain boundaries. The retention of Fe around the grain (Figs. $3 \mathrm{a}$ vs. $3 \mathrm{~b}$ and $4 \mathrm{~d}$ vs. $4 \mathrm{c}$ ) indicates a higher $\mathrm{pH}$ environment and corresponding lower solubility of Fe, which produces substantial Fe distal precipitates. humidity cell (b, d, e, f, and h) and test pile (a, c, and g) experiments performed as part of the Diavik Waste Rock 
Project. The first row contains reflected light images of fractured grains from the least weathered (a) to the most weathered (d). The second row contains transmitted light images of the same grains. The third and fourth rows are similarly arranged images of unfractured grains.

Fig. 4. Different physical and chemical characteristics of weathered pyrrhotite grains in waste rock collected from the humidity cell (c, d, e, f, g, and h) and test pile (a and b) experiments performed as part of the Diavik Waste Rock Project. These characteristics influence weathering or are a result of weathering. The first and third rows are SEM images of the grains with noted physical and chemical weathering characteristics, and the second and fourth rows are synchrotron $\mu$-XRF maps of S (green) and Fe (red) distribution.

Fig. 5. $\mathrm{S}$ and $\mathrm{Fe}$ abundances (as indicated by the emitted $\mathrm{x}$-ray intensity (counts)) for locations on weathered pyrrhotite grains in waste rock collected from the humidity cell and test pile experiments performed as part of the Diavik Waste Rock Project.

\subsection{Oxidative dissolution of pyrrhotite and $S$ speciation}

During the oxidation of pyrrhotite, the sulfide is transformed to a disulfide $\left(\mathrm{FeS}_{2}\right)$ and then to various intermediate compounds, such as elemental $\mathrm{S}\left(\mathrm{S}^{0}\right)$, sulfite $\left(\mathrm{SO}_{3}{ }^{2-}\right)$, and thiosulfate $\left(\mathrm{S}_{2} \mathrm{O}_{3}{ }^{2-}\right)$, prior to its full oxidation to $\mathrm{SO}_{4}{ }^{2-}$ (Nordstrom and Southam, 1997; Belzile et al., 2004; Blowes et al., 2003; Cruz et al., 2005). Using the XANES spectra, the oxidation states of S were examined at locations that were visibly less weathered or more weathered on selected pyrrhotite grains (Table 1; Fig. 6). The more oxidized $\mathrm{S}$ forms were found at locations near or on alteration layers and away from less altered areas. The sulfide forms were present at all locations and likely were underlying the oxidized species (penetration depth of the x-ray and fluorescence emission may be $30 \mu \mathrm{m}$ of the sample; Prietzel et al., 2011). The presence of $\mathrm{S}^{0}$ and $\mathrm{SO}_{3}{ }^{2-}\left[\mathrm{S}^{4+} \mathrm{O}_{3}\right]$ was more variable compared to the more frequently detected $\mathrm{S}_{2} \mathrm{O}_{3}{ }^{2-}\left[\mathrm{S}^{0} \mathrm{~S}^{4+} \mathrm{O}_{3}\right]$, which may be a result of the $\mathrm{pH}$ environment. Solid phase $\mathrm{S}_{2} \mathrm{O}_{3}{ }^{2-}$ is more stable below a pH of 7 than solid phase $\mathrm{SO}_{3}{ }^{2-}$ (Druschel et al., 2003). Previous studies of the evolution of sulfide to $\mathrm{SO}_{4}{ }^{2-}$ suggest that $\mathrm{S}_{2} \mathrm{O}_{3}{ }^{2-}$ (and various polythionates such as tetrathionate $\left[\mathrm{S}_{4} \mathrm{O}_{6}{ }^{2-}\right.$ or $\left.\mathrm{S}_{2}{ }^{0} \mathrm{~S}_{2}{ }^{5+} \mathrm{O}_{6}\right]$ ) is a precursor of $\mathrm{SO}_{4}{ }^{2-}$ (reviewed by Druschel et al., 2003). The $\mathrm{S}_{2} \mathrm{O}_{3}{ }^{2-}$ and $\mathrm{S}_{4} \mathrm{O}_{6}{ }^{2-}$ are more stable than $\mathrm{S}^{0}$ and $\mathrm{SO}_{3}{ }^{2-}$, and thus can form other polythionates that oxidize to $\mathrm{SO}_{4}{ }^{2-}$ at rates slower than the formation of $\mathrm{S}_{2} \mathrm{O}_{3}{ }^{2-}$ (Druschel et al., 2003). Suzuki (1999) described the formation of $\mathrm{S}_{2} \mathrm{O}_{3}{ }^{2-}$ through the accumulation of $\mathrm{SO}_{3}{ }^{2-}$ and presence of $\mathrm{S}^{0}$. The $\mathrm{S}_{2} \mathrm{O}_{3}{ }^{2-}$ on the pyrrhotite likely was more stable in this weathering environment than $\mathrm{S}^{0}$ or $\mathrm{SO}_{3}{ }^{2-}$. The nucleophilicity of these compounds is dependent on the $\mathrm{pH}$, and acidic conditions $(\mathrm{pH}<5)$ will drive the $\mathrm{SO}_{3}{ }^{2-}$ to $\mathrm{S}_{2} \mathrm{O}_{3}{ }^{2-}$ reaction towards $\mathrm{SO}_{3}{ }^{2-}$ (Suzuki, 1999). The 
greater presence of $\mathrm{S}_{2} \mathrm{O}_{3}{ }^{2-}$ suggests limited acid generation during the weathering of this pyrrhotite in this low sulfide waste rock.

Table 1. Presence of reduced, elemental, and oxidized forms of S at inner (less weathered) or outer (more weathered) locations on pyrrhotite grains in waste rock collected from the humidity cell and test pile experiments performed as part of the Diavik Waste Rock Project. The presence of a $\mathrm{S}$ form was determined through comparison with XANES spectra from $\mathrm{S}$ standards.

[Weathered state, weathered state of grain per Blowes and Jambor's (1990) sulfide alteration index with location of weathering (laboratory or field site); po, pyrrhotite; pn, pentlandite; mrc, marcasite; inner, inner area away from weathering rims; outer, outer rims where oxidation is optically visible; inner lamella, at or near a pentlandite lamella within a pyrrhotite grain; outer lamella, at or near a pentlandite lamella at or near the edge of the pyrrhotite grain]

\begin{tabular}{|c|c|c|c|c|c|c|c|c|}
\hline Sample & $\begin{array}{l}\text { Grain } \\
\text { location }\end{array}$ & $\begin{array}{l}\text { Weathered } \\
\text { state }\end{array}$ & $\begin{array}{l}{ }^{\text {a Sulfide }} \\
\text { (po, pn) }\end{array}$ & $\begin{array}{l}\text { Disulfide } \\
\text { (mrc) }\end{array}$ & Elemental & Sulfite & Thiosulfate & Sulfate \\
\hline \multicolumn{9}{|c|}{ Pyrrhotite with diffuse Ni } \\
\hline Fig. $6 a$ & $\begin{array}{l}\text { Inner } \\
\text { Outer }\end{array}$ & 2 (field) & & & & & & \\
\hline Fig. $6 \mathrm{~b}$ & $\begin{array}{l}\text { Inner } \\
\text { Outer }\end{array}$ & 3 (lab) & $\begin{array}{l}\text { po } \\
\text { po }\end{array}$ & & & & & \\
\hline Fig. 6c & $\begin{array}{l}\text { Inner } \\
\text { Outer }\end{array}$ & 4 (lab) & $\begin{array}{l}\text { po } \\
\text { po }\end{array}$ & & & & & \\
\hline Fig. 6d & $\begin{array}{l}\text { Inner } \\
\text { Outer }\end{array}$ & 8 (lab) & $\begin{array}{l}\text { po } \\
\text { po }\end{array}$ & & & & & \\
\hline \multicolumn{9}{|c|}{ Pyrrhotite with concentrated Ni in pentlandite lamella, position near the lamella } \\
\hline Fig. 6e & $\begin{array}{l}\text { Inner } \\
\text { Outer }\end{array}$ & 3 (field) & $\begin{array}{l}\text { po, pn } \\
\text { po, pn }\end{array}$ & & & & & \\
\hline Fig. $6 f$ & $\begin{array}{l}\text { Inner } \\
\text { Outer }\end{array}$ & 4 (field) & $\begin{array}{l}\text { po, pn } \\
\text { po, pn }\end{array}$ & & & & & \\
\hline
\end{tabular}

${ }^{a}$ Pyrrhotite (po) and pentlandite (pn) are the expected sulfide forms. The abbreviations are included in the matrix where po and pn were detected.

Fig. 6. Weathered pyrrhotite grains in waste rock collected from the humidity cell (b, c, and d) and test pile (a, e, and f) experiments performed as part of the Diavik Waste Rock Project. Images are shown as transmitted (first) light and reflected (second) light images and element distribution maps from synchrotron $\mu$-XRF that combine $\mathrm{S}$ (green), Fe (red), and $\mathrm{Ni}$ (blue) to form $\mathrm{S}-\mathrm{Fe}$ (third) and $\mathrm{S}-\mathrm{Ni}$ (fourth) images. The images represent pyrrhotite with diffuse $\mathrm{Ni}-$ minimally weathered (a), pyrrhotite with diffuse $\mathrm{Ni}$ - weathered with alteration layers (b), fractured pyrrhotite with diffuse $\mathrm{Ni}$ - weathered (c), fractured pyrrhotite with diffuse $\mathrm{Ni}$ - heavily weathered with $\mathrm{Ni}$ retention in distal Fe precipitates (d), pyrrhotite with internal and external pentlandite lamella-weathered (e), and pyrrhotite with external pentlandite lamella - weathered (f).

Sulfur XANES spectra for the bulk sulfide samples indicate the presence of similar $\mathrm{S}$ oxidation states compared to the individual grains (Table 1, Fig. 7). With weathering of the bulk pyrrhotite in the rock, the reduced $S$ is oxidized to $-1,0,+4$, and +6 oxidation states, but all $S$ forms remain present during all stages of weathering. The continued presence of the reduced forms of $\mathrm{S}$ are a result of mixed weathering states in samples and the oxidized layers overlying disulfide and sulfide layers. This evolution from sulfide/disulfide at depth to oxidized species near the 
surface is an illustration of the shrinking core concept and passivation of sulfide oxidation. The Fe (oxyhydr)oxides can reduce the entrance of oxygen and water to the oxidizing sulfide core (Grosvenor et al., 2004; Lu and Wang, 2012); thereby reducing the potential release of S and Ni because of reduced weathering and the potential sorption of $\mathrm{Ni}$ to this new substrate (Hochella et al., 1999; Jamieson, 2011). The smaller presence $\mathrm{SO}_{4}{ }^{2-}$ compared to $\mathrm{S}_{2} \mathrm{O}_{3}{ }^{2-}$ in the weathered zones (Table 1) indicates the loss of $\mathrm{S}_{\text {as }} \mathrm{SO}_{4}{ }^{2-}$ from the grain once full oxidation occurs. The hydrophilic nature of $\mathrm{SO}_{4}{ }^{2-}$ (hydration of the anion charge) allows it to more readily enter solution compared to less oxidized forms.

Fig. 7. S XANES spectra of bulk pyrrhotite samples collected from the humidity cell and test pile experiments performed as part of the Diavik Waste Rock Project. Gray bars are the inflection points or maxima of the first derivative for the absorption spectra of the indicated standard $\left(\mathrm{E}_{0}\right)$.

Schippers and Sand (1998) describe two metal-sulfide oxidation mechanisms (pathways)—via thiosulfate or polysulfide-where the sulfide is either oxidized to $\mathrm{S}_{2} \mathrm{O}_{3}{ }^{2-}$ then to $\mathrm{SO}_{4}{ }^{2-}$ or from sulfide to a polysulfide such as $\mathrm{S}_{8}\left(\mathrm{~S}^{0}\right)$ prior to oxidation to $\mathrm{SO}_{4}{ }^{2-}$. The $\mathrm{SO}_{3}{ }^{2-}$ is an intermediate compound in both pathways. The presence of $\mathrm{Fe}$ and $\mathrm{O}_{2}$ during the oxidation of sulfide minerals tends to favor the thiosulfate pathway (Druschel et al., 2003; Schippers and Sands, 1998; Suzuki, 1999). The strong presence of $\mathrm{S}_{2} \mathrm{O}_{3}{ }^{2-}$ (Table 1, Fig. 7) along with the presence of Fe and oxic conditions during the experiments suggests that the thiosulfate pathway is the oxidation mechanism for $\mathrm{S}$ in this setting. The presence of $\mathrm{S}_{2} \mathrm{O}_{3}{ }^{2-}$ also indicates the likely formation of polythionates such as $\mathrm{S}_{4} \mathrm{O}_{6}{ }^{2-}$ (Druschel et al., 2003; Suzuki, 1999).

Prange et al. (2002) describe differences in $\mathrm{S}_{2} \mathrm{O}_{3}{ }^{2-}$ and $\mathrm{S}_{4} \mathrm{O}_{6}{ }^{2-}$ XANES spectra, which are differentiated by a greater $\mathrm{S}^{0}$ absorption signal for $\mathrm{S}_{4} \mathrm{O}_{6}{ }^{2-}$. This greater $\mathrm{S}^{0}$ absorption for $\mathrm{S}_{4} \mathrm{O}_{6}{ }^{2-}$ appears to be present in the second most weathered sample shown in Fig. 7. Because the thiosulfate pathway was the primary pathway for $\mathrm{S}$ oxidation in this system, the greater $\mathrm{S}^{0}$ response in the weathered spectra likely represents a polythionate, such as $\mathrm{S}_{4} \mathrm{O}_{6}{ }^{2-}$, and not a response from polysulfides (alternate pathway). The continued oxidation of an individual pyrrhotite grain will produce a shift from the $\mathrm{S}^{0}$-rich signal to a greater presence of $\mathrm{SO}_{3}{ }^{2-}$ and 
$\mathrm{S}_{2} \mathrm{O}_{3}{ }^{2-}$, which is visible on individual grains when comparing less-weathered (Fig. 8, inner grain) and more-weathered locations (Fig. 8, outer grain). Given the likely thiosulfate pathway and presence of polythionates, this shift in the spectra from the $\mathrm{S}^{0}$-rich signal to $\mathrm{SO}_{3}{ }^{2-}$ and $\mathrm{S}_{2} \mathrm{O}_{3}{ }^{2-}$ represents a cleavage of the polythionates and formation of greater concentrations of $\mathrm{S}_{2} \mathrm{O}_{3}{ }^{2-}$. Additionally, the greater presence of $\mathrm{SO}_{4}{ }^{2-}$ occurs with this shift to the more oxidized $\mathrm{S}$ forms, which is observed in the strong elemental signal at the inner grain location and a more oxidized signal at the more weathered location (Fig. 8, outer grain).

Fig. 8. S XANES spectra for less weathered (inner grain) and more weathered (outer grain) locations on an individual pyrrhotite grain (Fig. 6d) from waste rock collected as part of the Diavik Waste Rock Project.

\subsection{Changes in Ni coordination during $S$ oxidation}

The retention or release of $\mathrm{Ni}$ during weathering of pyrrhotite is dependent on the oxidation of $\mathrm{S}$ and $\mathrm{Fe}$ (alteration of the crystal structure), the subsequent formation of secondary mineral phases, and the $\mathrm{pH}$ of the microenvironment, which can be different than the $\mathrm{pH}$ of the surrounding environment (Dockrey et al., 2014). The distribution of $\mathrm{Ni}$ in the pyrrhotite grains occurred in two forms: 1) Ni distributed throughout the grain (diffusely distributed) and 2) pentlandite lamella (Fig. 6). Pyrrhotite containing diffusely distributed Ni was more common. Both forms of Ni-bearing pyrrhotite likely have similar bulk Fe:Ni ratios (near 200:1, as described by Jambor (1997)), but the differences in Ni distribution can influence the amount of Ni released because of the encapsulation of the pentlandite (Fig. 6e), which may slow weathering of the pentlandite lamellae. Retardation of Ni release because of pentlandite encapsulation is consistent with the observation of greater Ni release rates from Ni-bearing pyrrhotite compared to pyrrhotite with pentlandite lamellae (Ke and $\mathrm{Li}, 2006)$.

Although Ni remains in the +2 oxidation state under these conditions, its movement from the sulfide crystal structure to solution implies a change in coordination. Nickel was found coordinated with sulfide in minimally-weathered pyrrhotite and pentlandite; with weathering, the crystal structure was altered by the oxidation of $\mathrm{S}$ and $\mathrm{Fe}$ and $\mathrm{Ni}$ coordinated with oxygen to form 
$\mathrm{NiO}$ or $\mathrm{NiSO}_{4}$. This change in coordination is visible as a shift in the peak position and a sharpening of the peak in the Ni K-edge spectra (Fig. 9). Nickel in weathered pyrrhotite, with or without pentlandite lamella, indicates mixed coordination, which is a result of the presence of both Ni sulfide and Ni oxide species. Spectra obtained from weathered pyrrhotite that contained diffusely distributed $\mathrm{Ni}$ indicate a greater extent of oxide coordination at locations closer to the altered grain edges (Fig. 9b). Spectra obtained from oxidized pyrrhotite with Ni present in pentlandite lamellae indicate limited oxide coordination near the oxidizing pentlandite. Additionally, the Ni abundance (as determined by the intensity of absorbance (counts)) decreased with the shift to oxide coordination, indicating that Ni leaves the grain following conversion to the $\mathrm{NiO}$ or $\mathrm{NiSO}_{4}$ forms. This relation is similar to the release of $\mathrm{S}$ from the grain following complete oxidation, and results in the strong correlation between the dissolved $\mathrm{Ni}$ and $\mathrm{S}$ species (Fig. 2).

Fig. 9. Normalized XANES spectra for Ni standards with coordination to sulfides and oxides and a) weathered pyrrhotite with distributed $\mathrm{Ni}$ in the crystal structure and $\mathrm{b}$ ) weathered pyrrhotite with concentrated $\mathrm{Ni}$ as pentlandite lamella from waste rock samples collected from the humidity cell and test pile experiments performed as part of the Diavik Waste Rock Project.

\subsection{Mineral phases of Fe and Ni mobility}

The various oxidation states and mineral phases of $\mathrm{Fe}$ and $\mathrm{S}$ in weathering pyrrhotite depend on the availability of oxygen and water, solution pH, and temperature (Chiriţă and Rimstidt, 2013). Iron has been described as migrating from the S-rich layer, forming Fe (oxyhydr)oxides, and retarding oxygen penetration with formation of $\mathrm{Fe}^{3+}$ mineral phases (Mycroft et al., 1995; Thomas et al., 1998). Common secondary precipitates, including $\alpha-\mathrm{FeO}(\mathrm{OH}), \gamma-\mathrm{FeO}(\mathrm{OH})$, and $\mathrm{Fe}_{2} \mathrm{O}_{3} \cdot 0.5 \mathrm{H}_{2} \mathrm{O}$, are typically associated with sulfide oxidation, and other Fe oxidation products

such as $\mathrm{Fe}^{2+} \mathrm{Fe}^{3+}{ }_{2} \mathrm{O}_{4}$ and $\mathrm{Fe}_{2} \mathrm{O}_{3}$ are less common (Blowes et al., 2003). To examine the possible influence of $\mathrm{Fe}$ on the mobility of $\mathrm{Ni}$, the $\mathrm{Fe}$ (oxyhydr)oxides present on the weathered pyrrhotite grains were investigated using $\mu$-XRD. Identification of Fe minerals at specific grain locations was not possible because of the variability of the weathered surface and size of the distal Fe precipitates compared to the size of the collimator aperture. The $\mu$-XRD beam was placed near the 
part of a weathered grain where primarily Fe alteration zones and(or) distal Fe precipitates were concentrated. The $\mu$-XRD diffraction patterns from well-weathered parts of pyrrhotite grains (Figs. $3 \mathrm{~b}, \mathrm{~d}$ and $4 \mathrm{f}$ ) indicate the remaining presence (high confidence based on peak identification) of $\mathrm{Fe}$ sulfide $\left(\mathrm{Fe}_{7} \mathrm{~S}_{8}\right.$ and $\mathrm{FeS}_{2}$ ) along with $\alpha-\mathrm{FeO}(\mathrm{OH})$ (high confidence), $\gamma-\mathrm{FeO}(\mathrm{OH})$ (high), $\mathrm{Fe}_{2} \mathrm{O}_{3} \cdot 0.5 \mathrm{H}_{2} \mathrm{O}$ (high), $\mathrm{Fe}^{2+} \mathrm{Fe}^{3+}{ }_{2} \mathrm{O}_{4}$ (high), and $\mathrm{Fe}_{2} \mathrm{O}_{3}$ (low confidence). These $\mathrm{Fe}$ mineral phases provide a surface for the sorption of $\mathrm{Ni}$ in the alteration layers/zones of the grain or in the distal $\mathrm{Fe}$ precipitates. Adsorption is expected at near-neutral $\mathrm{pH}$ in the presence of $\alpha-\mathrm{FeO}(\mathrm{OH})$ (Bruemmer et al., 1988; Rose and Bianchi-Mosquera, 1993), amorphous $\mathrm{Fe}(\mathrm{OH})_{3}$ (Green-Pedersen et al., 1997), $\mathrm{Fe}^{2+} \mathrm{Fe}^{3+}{ }_{2} \mathrm{O}_{4}$ (Nassar, 2012), $\mathrm{Fe}_{2} \mathrm{O}_{3} \cdot 0.5 \mathrm{H}_{2} \mathrm{O}$ (Stumm and Morgan, 1996), $\mathrm{Fe}_{2} \mathrm{O}_{3}$ (McKenzie, 1980), and iron oxide nanoparticles (Nassar, 2012; Salmani et al., 2013). McKenzie (1980) found stronger $\mathrm{Ni}$ sorption on $\alpha-\mathrm{FeO}(\mathrm{OH})$ for a $\mathrm{pH}$ range of 5-6, and stronger sorption on $\mathrm{Fe}_{2} \mathrm{O}_{3}$ for a $\mathrm{pH}$ range of 6-7. The preference of $\mathrm{Ni}$ for a specific Fe mineral phase could not be determined within the broader analysis of the Fe mineral phases on the grains or in the distal precipitates, but the continued release of Ni into solution under near-neutral conditions (Fig. 2) and without the presence of a corresponding release of Fe suggests desorption of Ni with continued weathering.

The presence and retention of $\mathrm{Ni}$ in the grain system depends on its initial distribution within the grain — diffuse within the pyrrhotite (Fig. 6a) or as pentlandite lamella (Fig. 6d) —and the $\mathrm{pH}$ of the local solution. Loss of Ni from pyrrhotite with diffusely distributed Ni (Fig. 6a) should occur with dissolution of any weathered zone. Pyrrhotite grains with pentlandite lamella (Fig. 6d) have concentrated $\mathrm{Ni}$ sources that can oxidize and release from this source and create diffusion patterns emanating away from the lamella because of limited solubility (Fig. 6e). With a lack of mobility in solution because of higher $\mathrm{pH}, \mathrm{Ni}$ is retained in the grain system but appears to be concentrated in the distal Fe precipitates (Fig. 6d). The presence of Ni released from the pentlandite lamella and accumulated in Fe mineral phases also is evident (Fig. 6e,f). Nickel is released with oxidation of the pentlandite and either adsorbed or precipitated with the Fe minerals. Weathered grains with pentlandite lamella (Fig. 6d,e) contained $\mathrm{Fe}_{7} \mathrm{~S}_{8}$ and $\mathrm{FeS}_{2}$ (high confidence) 
as well as $\alpha-\mathrm{FeO}(\mathrm{OH}), \gamma-\mathrm{FeO}(\mathrm{OH}), \mathrm{Fe}_{2} \mathrm{O}_{3} \cdot 0.5 \mathrm{H}_{2} \mathrm{O}, \mathrm{Fe}^{2+} \mathrm{Fe}^{3+}{ }_{2} \mathrm{O}_{4}$, and $\mathrm{Fe}_{2} \mathrm{O}_{3}$ (high and low) depending on location towards the center or edge of the grain.

\section{Summary and conclusions}

The oxidation of $\mathrm{S}$, distribution and coordination of $\mathrm{Ni}$, and possible adsorption of $\mathrm{Ni}$ on $\mathrm{Fe}$ mineral phases with weathering of a 4C (monoclinic) pyrrhotite in a low sulfide waste rock was examined to understand the geochemical evolution of the pyrrhotite and release of these elements into solution. The weathering of the pyrrhotite produced various physical characteristics including surface etching, alteration layers, and formation of distal Fe precipitates in close proximity to the sulfide grains. The release of $\mathrm{S}$ and $\mathrm{Ni}$ occurred through oxidative dissolution of the pyrrhotite, and the release of $\mathrm{Ni}$ was influenced by its distribution in the grain: diffuse distribution throughout the grain or concentrated in pentlandite lamellae. With release from pyrrhotite, the concentrations of $\mathrm{S}$ and $\mathrm{Ni}$ in solution were strongly correlated under acidic $\mathrm{pH}$, but this correlation weakened with near-neutral $\mathrm{pH}$ because of a decrease in Ni solubility.

Sulfur was present in the $-2,-1,0,+4$, and +6 oxidation states across weathered zones prior to its release from the pyrrhotite as $\mathrm{SO}_{4}{ }^{2-}$. The presence of the various oxidation states of $\mathrm{S}$ in weathered pyrrhotite is an example of the shrinking core concept of sulfide oxidation and passivation of the sulfide mineral. Oxidized S species overlay less oxidized S species in an alteration zone that is migrating into the pyrrhotite with continued oxidation, although a range of $\mathrm{S}$ species may also be found near the surface of the grains because of uneven weathering across the grain surface. Sulfur in its $\mathrm{S}_{2} \mathrm{O}_{3}{ }^{2-}$ form was more persistent than $\mathrm{SO}_{3}{ }^{2-}$ prior to oxidation to $\mathrm{SO}_{4}{ }^{2-}$, which is indicative of the thiosulfate pathway of metal-sulfide oxidation. Additional evidence of the thiosulfate pathway of S oxidation was the likely formation of polythionates that preceded an accumulation of $\mathrm{S}_{2} \mathrm{O}_{3}{ }^{2-}$.

Nickel was primarily coordinated with reduced $\mathrm{S}$ in the pyrrhotite, but near well-weathered 
parts of a grain, $\mathrm{Ni}$ was bonded with oxygen as $\mathrm{NiO}$ and $\mathrm{NiSO}_{4}$. This change in coordination represents the release state of $\mathrm{Ni}$ and the reason for its strong correlation to $\mathrm{SO}_{4}{ }^{2-}$ in leachate. The release of Ni from pyrrhotite was not strongly correlated with the release of Fe; however, Ni can adsorb on Fe (oxyhydr)oxides within the alteration zones of the weathered pyrrhotite. In some grains, Ni was found concentrated in Fe (oxyhydr)oxides that formed as distal precipitates in close proximity to the grains because of the surrounding $\mathrm{pH}$ conditions and slow dissolution. Adsorption of $\mathrm{Ni}$ on $\mathrm{Fe}$ (oxyhydr)oxides likely is enhanced in near-neutral $\mathrm{pH}$ conditions, which can limit the release of Ni into solution. This improved understanding of the oxidation pathway of S, coordination and release of $\mathrm{Ni}$, and influence of $\mathrm{Fe}$ (oxyhydr)oxides in the weathering of pyrrhotite will assist in determining appropriate reaction-rate factors and element release rates for prediction of acid rock drainage.

\section{Acknowledgements}

The cooperation of many individuals and organizations was essential for completion of this study. Funding for this research was provided by a Collaborative Research and Development Grant from the Natural Sciences and Engineering Research Council of Canada (NSERC) awarded to D.W. Blowes, Principal Investigator; Diavik Diamond Mines, Inc.; an Innovation Fund Award from the Canada Foundation for Innovation (CFI) awarded to James F. Barker, Principal Investigator; the International Network for Acid Prevention; and the Mine Environment Neutral Drainage Program. The authors acknowledge the assistance of David Nguyen, Priyanca Patel, Katherine Raymond, Jeff Sparks, Adrienne Trac, Kristen Wesenberg, Elaine Wong, and Peter Wray at the University of Waterloo in collecting and preparing samples. Use of the Advanced Photon Source, an Office of Science User Facility operated for the U.S. Department of Energy (DOE) Office of Science by Argonne National Laboratory, was supported by the U.S. DOE under Contract No. DE-AC02-06CH11357. Use of the Canadian Light Source is funded by the CFI, NSERC, the National Research Council Canada, the Canadian Institutes of Health Research, the 
Government of Saskatchewan, Western Economic Diversification Canada, and the University of

Saskatchewan.

\section{References}

Alpers, C.N., Blowes, D.W., Nordstrom, D.K., Jambor, J.L., 1994. Secondary minerals and acid mine-water chemistry. In: Jambor, J.L., Blowes, D.W. (Eds.), Environmental Geochemistry of Sulfide Mine-Wastes, vol. 22. Mineral. Assoc. Can. Short Course, pp. 245-270.

Appelo, C.A.J., Postma, D., 2005. Geochemistry, Groundwater and Pollution, 2nd ed., Taylor \& Francis, Amsterdam, $649 \mathrm{p}$.

Arnold, R.G., 1966. Mixtures of hexagonal and monoclinic pyrrhotite and the measurement of the metal content of pyrrhotite by x-ray diffraction. Am. Mineral. 51, 1221-1227.

ASTM Standard D5744, 2013. Standard test method for laboratory weathering of solid materials using a humidity cell. ASTM International, West Conshohocken, PA.

Becker, U., Munz, A.W., Lennie, A.R., Thornton, G., Vaughan, D.J., 1997. The atomic and electronic structure of the (001) surface of monoclinic pyrrhotite $\left(\mathrm{Fe}_{7} \mathrm{~S}_{8}\right)$ as studied using STM, LEED and quantum mechanical calculations. Surf. Sci. 389, 66-87.

Belzile, N., Chen, Y.W., Cai, M.F., Li, Y., 2004. A review on pyrrhotite oxidation. J. Geochem. Explor. 84, 65-76.

Blowes, D.W., Jambor, J.L., 1990. The pore-water geochemistry and the mineralogy of the vadose zone of sulfide tailings, Waite Amulet, Quebec, Canada. Appl. Geochem. 5, 327-346.

Blowes, D.W., Logsdon, M.J., 1998. Diavik geochemistry baseline report. Prepared by Sala Groundwater, Inc. and Geochimica, Inc. for Diavik Diamond Mines and submitted to Canadian Environmental Assessment Agency, $121 \mathrm{p}$.

Blowes, D.W., Ptacek, C.J., Jambor, J.L., Weisener, C.G., 2003. The geochemistry of acid mine drainage. In: Lollar, B.S. (Ed.), Environmental Geochemistry, 9, Treatise on Geochemistry, Elsevier-Pergamon, pp. 149-204.

Boujelben, J., Elouear, B.Z., 2009. Adsorption of nickel and copper onto natural iron oxide-coated sand from aqueous solutions: Study in single and binary systems. J. Hazard. Mater. 163, 376-382.

Bruemmer, G.W., Gerth, J., Tiller, K.G., 1988. Reaction kinetics of the adsorption and desorption of nickel, zinc and cadmium by goethite: I. Adsorption and diffusion of metals. J. Soil Sci. 39, 37-52.

Buckley, A.N., Woods, R., 1985. X-ray photoelectron spectroscopy of oxidized pyrrhotite surfaces: I. Exposure to aqueous solutions. Appl. Surf. Sci. 20, 472-480.

Cathles, L.M., 1979. Predictive capabilities of a finite difference model of copper leaching in low grade industrial sulfide waste dumps. Math. Geo. 11(2), 175-191.

Chen, Y.W., Li, Y., Cai, M.F., Belzile, N., Dang, Z., 2006. Preventing oxidation of iron sulfide minerals by polyethylene polyamines. Min. Eng. 19(1), 19-27. 
Chiriţă, P., Rimstidt, J.D., 2014. Pyrrhotite dissolution in acidic media. App. Geochem., 41, 1-10.

Cornell, R.M., 1991. Simultaneous incorporation of Mn, Ni and Co in the goethite structure. Clay Min. 26, 427-430.

Cruz, R., González, I., Monroy, M., 2005. Electrochemical characterization of pyrrhotite reactivity under simulated weathering conditions. Applied Geochemistry 20, 109-121.

Davis, G.B., Ritchie, A.I.M., 1986. A model of oxidation in pyritic mine wastes. I. Equations and approximate solution. Appl. Math. Modelling 10, 314-322.

Davis, G.B., Ritchie, A.I.M., 1987. A model of oxidation in pyritic mine wastes: Part 3: import of particle size distribution. Appl. Math. Modelling 11, 417-422.

Davis, G.B., Doherty, G., Ritchie, A.I.M., 1986. A model of pyrite oxidation in mine wastes. II. Comparison of numerical and approximate solutions. Appl. Math. Modelling 10, 323-329.

de Villiers, J.P.R., Liles, D.C., 2010. The crystal-structure and vacancy distribution in 6C pyrrhotite. Amer. Mineralogist 95, 148-152.

de Villiers J.P.R., Liles D.C., Becker, M., 2009. The crystal structure of a naturally occurring 5C pyrrhotite from Sudbury, its chemistry, and vacancy. Amer. Mineral. 94, 1405-1405.

Dockrey, J.W., Lindsay, M.B.J., Mayer, K.U., 2014. Acidic microenvironments in waste rock characterized by neutral drainage: bacteria-mineral interactions at sulfide surfaces. Minerals 4, 170-190.

Druschel, G.K., Hamers, R.J., Banfield, J.F., 2003. Kinetics and mechanism of polythionate oxidation to sulfate at low pH by $\mathrm{O} 2$ and $\mathrm{Fe}^{3+}$. Geochim. Cosmochim. Acta 67(23), 4457-4469.

Elliot, A.D., 2010. Structure of pyrrhotite 5C $\left(\mathrm{Fe}_{9} \mathrm{~S}_{10}\right)$. Acta Crystallogr. B 66, 271-279.

Environment Canada, 2013. Monthly data report for Ekati A, Northwest Territories. Accessible at: climate.weatheroffice.ec.gc.ca/climateData/canada_e.html, accessed July 2013.

Etschmann, B., Pring, A., Putnis, A., Grguric, B.A., Studer, A., 2004. A kinetic study of the exsolution of pentlandite $(\mathrm{Ni}, \mathrm{Fe})_{9} \mathrm{~S}_{8}$ from the monosulfide solid solution (Fe,Ni)S. Amer. Mineral. 89, 39-50.

Fleet, M.E., 1978. The pyrrhotite—-marcasite transformation. Can. Mineral. 16, 31-35.

Fowler, T.A., Crundwell, F.K., 1999. Leaching of zinc sulfide by thiobacillus ferrooxidans: bacterial oxidation of the sulfur product layer increases the rate of zinc sulfide dissolution at high concentrations of ferrous ions. Appl. Environ Microbiol. 65(12), 5285-5292.

Galan, E., Gomez-Hriza, J.L., Gonzales, I., Fernandez-Caliani, J.C., Morales, E., Giraldez, I., 2003. Heavy metal partitioning in river sediments severely polluted by acid mine drainage in the Iberian pyrite belt. Appl. Geochem. 18, 409-421.

Green-Pedersen, H., Jensen, B.T., Pind, N., 1997. Nickel adsorption on $\mathrm{MnO}_{2}, \mathrm{Fe}(\mathrm{OH})_{3}$, montmorillonite, humic acid and calcite. Env. Tech. 18(8), 807-815.

Grosvenor, A.P., Kobe, B.A., McIntyre, N.S., 2004. Examination of the oxidation of iron by oxygen using X-ray photoelectron spectroscopy and QUASESTM. Surface Science 565, 151-162.

Gunsinger, M., Ptacek, C.J., Blowes, D.W., Jambor, J.L., 2006. Evaluation of long-term sulfide oxidation processes within pyrrhotite-rich tailings, Lynn lake, Manitoba. J. Contam. Hydrol. 83, 149-170. 
Hawley, J.E., 1962. The Sudbury ores: their mineralogy and origin. Can. Mineral. 7, p. 1-207.

Harries, D., Pollok, K., Langenhorst, F., 2013. Oxidative dissolution of 4C- and NC-pyrrhotite: intrinsic reactivity differences, $\mathrm{pH}$ dependence, and the effect of anisotropy. Geo. Cos. Acta 102, 23-44.

Hochella Jr, M.F., Moore, J.N., Golla, U., Putnis, A., 1999. A TEM study of samples from acid mine drainage systems: metal-mineral association with implications for transport. Geochimica et Cosmochimica Acta 63, 3395-3406.

Jambor, J.L., 1997. Mineralogy of the Diavik Lac de Gras kimberlites and host rocks. Prepared by Leslie Investment, Ltd. for Diavik Diamond Mines and submitted to the Canadian Environmental Assessment Agency, 1997, 187 p.

Janzen, M.P., 1996. Role of ferric iron, trace metal content, and crystal structure on pyrrhotite oxidation. M.Sc. Thesis, Univ. Waterloo, Waterloo, Ontario.

Janzen, M.P., Nicholson, R.V., Scharer, J.M., 2000. Pyrrhotite reaction kinetics: reaction rates for oxidation by oxygen, ferric iron, and for nonoxidative dissolution, Geochem. Cosmochem. Acta 64(9), 1511-1522.

Kalinkin, A.M., Forsling, W., Makarov, D.V., Makarov, V.N., 2000. Surface oxidation of synthetic pyrrhotite during wetting-drying treatment. Environ. Eng. Sci. 17, 329-335.

Ke, J., Li, H., 2006. Bacterial leaching of nickel-bearing pyrrhotite. Hydrometallurgy 82(3-4), 172-175.

Langman, J.B., Moore, M.L., Ptacek, C.J., Smith, L., Sego, D., Blowes, D.W., 2014. Diavik Waste Rock Project: evolution of mineral weathering, element release, and acid generation and neutralization during a 5-year humidity cell experiment. Minerals 4(2), 257-278.

Lee, G., Bigham, J.M., Faure, G., 2002. Removal of trace metals by coprecipitation with Fe, Al and Mn from natural waters contaminated with acid mine drainage in the Ducktown mining district, Tennessee. Appl. Geochem. 17, 569-581.

Levenspiel, O., 1972. Chemical Reaction Engineering, 2nd ed., John Wiley \& Sons, New York, 361-371.

Lu, X., Wang, H., 2012. Microbial oxidation of sulfide tailings and the environmental consequences. Elements 8, 119-124.

Mayer, K.U., Frind, E.O., Blowes, D.W., 2002. Multicomponent reactive transport modeling in variably saturated porous media using a generalized formulation for kinetically controlled reactions. Water Resour. Res. 38(9), 13-1-21.

McKenzie, R.M., 1980. The adsorption of lead and other heavy metals on oxides of manganese and iron. Aust. J. Soil Res. 18, 61-73.

Mikhlin, Y.L., Kuklinskii, A.V., Pavlenko, N.I., Varnek, V.A., Asonov, I.P., Okotrub, A.V., Selyutin, G.E., Solovyev, L.A., 2002. Spectroscopic and XRD studies of the air degradation of acid reacted pyrrhotite. Geochim. Cosmochim. Acta 66, 4057-4067.

Mycroft, J.R., Nesbitt, H.W., Pratt, A.R., 1995. X-ray photoelectron and Auger electron spectroscopy of airoxidized pyrrhotite: distribution of oxidized species with depth. Geochim. Cosmochim. Acta 59, 721733.

Naldrett, A.J., Craig, J.R., Kullerud, G., 1967. The central portion of the Fe-Ni-S system and its bearing on pentlandite exsolution in iron-nickel sulfide ores. Econ. Geo. 62, 826-847. 
Nassar, N.N., 2012. Kinetics, equilibrium and thermodynamic studies on the adsorptive removal of nickel, cadmium and cobalt from wastewater by superparamagnetic iron oxide nanoadsorbents. Can. J. Chem. Eng. 90(5), 1231-1238.

Neuner, M., Smith, L., Blowes, D.W., Sego, D.C., Smith, L.J.D., Fretz, N., Gupton, M., 2013. The Diavik Waste Rock Project: water flow though waste rock in a permafrost terrain. Appl. Geochem. 36, 222-233.

Nordstrom, D.K., 2011. Hydrogeochemical processes governing the origin, transport and fate of major and trace elements from mine wastes and mineralized rock to surface waters. App. Geochem. 26, 1777-1791.

Nordstrom, D.K., Alpers, C.N., 1999. Geochemistry of acid mine waters. In: Plumlee, G.S., Logston, M.D. (Eds.), The Environmental Geochemistry of Mineral Deposits: Part A. Processes, Methods, and Health Issues. Society of Economic Geologists, Reviews in Economic Geology, 6A, pp. 133-160.

Nordstrom, D.K., Southam, G., 1997. Geomicrobiology of sulfide mineral oxidation. Rev. Mineral. Geochem. 35, 361-390.

Orlova, T.A., Stupnikov, V.M., Krestan, A.L., 1989. Mechanism of oxidative dissolution of sulphides. Zhurnal Prikladnoi Khimii 61, 2172- 2177.

Pham, N.H., Sego, D.C., Arenson, L.U., Blowes, D.W., Amos, R.T., Smith, L., 2013. The Diavik Waste Rock Project: Measurement of the thermal regime of a waste-rock test pile in a permafrost environment, Appl. Geochem. 36, 234-245.

Pósfai, M., Sharp, T.G., Kontny, A., 2000. Pyrrhotite varieties from the $9.1 \mathrm{~km}$ deep borehole of the KTB project. Amer. Mineralogist 85, 1406-1415.

Plysunin, A.M., Mironov, A.G., Belomestrova, N.V., Chernigova, S.Y., 1990. Laboratory studies on goldbearing sulfide oxidation. Geokhimiya 1, 51-60.

Prange, A., Chauvistré, R., Modrow, H., Hormes, J., Trüper, H.G., Dahl, C., 2002. Quantitative speciation of sulfur in bacterial sulfur globules: X-ray absorption spectroscopy reveals at least three different species of sulfur. Microbio. 148, 267-276.

Prietzel, J., Kögel-Knabner, I., Thieme, J., Paterson, D., McNulty, I., 2011. Microheterogeneity of element distribution and sulfur speciation in an organic surface horizon of a forested histosol as revealed by synchrotron-based x-ray spectromicroscopy. Organic Geochem. 42(11), 1308-1314.

Ravel, B., Newville, M., 2005. ATHENA, ARTEMIS, HEPHAESTUS: Data analysis for X-ray absorption spectroscopy using IFEFFIT. J. Synchrotron Radiat. 12, 537-541.

Rose, A.W., Bianchi-Mosquera, G.C., 1993. Adsorption of $\mathrm{Cu}, \mathrm{Pb}, \mathrm{Zn}, \mathrm{Co}, \mathrm{Ni}$, and $\mathrm{Ag}$ on goethite and hematite: A control on metal mobilization from red beds into stratiform copper deposits. Econ. Geol. 88, 1226-1236.

Salmani, M.H., Ehrampoush, M.H., Aboueian-Jahromi, M., Askarishahi, M., 2013. Comparison between $\mathrm{Ag}(\mathrm{I})$ and $\mathrm{Ni}(\mathrm{II})$ removal from synthetic nuclear power plant coolant water by iron oxide nanoparticles. $\mathrm{J}$. Env. Health Sci. Eng. 11:21.

Savitzky, A., Golay, M.J.E., 1964. Smoothing and differentiation of data by simplified least squares procedures. Anal. Chem. 36 (8), 1627-1639.

Schippers, A., Sand, W., 1998. Bacterial leaching of metal sulfides proceeds by two indirect mechanisms via thiosulfate or via polysulfides and sulfur. Appl. Environ. Microbiol. 65(1), 319-321. 
Sinclair, S., 2014. Influence of freeze-thaw dynamics and spatial contributions on geochemical loading from a low sulfide waste-rock pile. MSc thesis, University of Waterloo, 126 p.

Smith, L.J.D., Bailey, B.L., Blowes, D.W., Jambor, J.L., Smith, L., Sego, D.C., 2013a. The Diavik Waste Rock Project: initial geochemical response from a low sulfide waste rock pile. Appl. Geochem. 36, 210221.

Smith, L.J.D., Blowes, D.W., Jambor, J.L., Smith, L., Sego, D., Neuner, M., 2013b. The Diavik Waste Rock Project: particle size distribution and sulfur characteristics of low-sulfide waste rock. Appl. Geochem. 36, 200-209.

Smith, L.J.D., Moncur, M.C., Neuner, M., Gupton, M., Blowes, D.W., Smith, L., Sego, D.C., 2013c. The Diavik Waste Rock Project: design, construction, and instrumentation of field-scale experimental wasterock piles, Appl. Geochem. 36 187-199.

Steger, H.F., Desjardins, L.E., 1977. Oxidation of sulphide minerals: 3. Determination of sulphate and thiosulphate in oxidised sulphide minerals. Talanta 24, 675-679.

Steger, H.F., Desjardins, L.E., 1978. Oxidation of sulphide minerals: 4. Pyrite, chalcopyrite and pyrrhotite. Chem. Geol. 23, 225-237.

Stumm, W. 1992. Chemistry of the solid-water interface: processes at the mineral-water and particle-water interface in natural systems. John Wiley, New York. 428 p.

Stumm, W., Morgan, J.J., 1996. Aquatic chemistry: chemical equilibria and rates in natural waters. WileyInterscience, New York, $1040 \mathrm{p}$.

Suzuki, I., 1999. Oxidation of inorganic sulfur compounds: Chemical and enzymatic reactions. Can. J. Microbiol. 45. 97-105.

Theis, T.L., Richter, R.O., 1980. Adsorption reactions of nickel species at oxide surfaces. In: Kavanaugh, M.C., Leckie, J.O. (Eds.), Particulates in Water: Characterization, Fate, Effects and Removal. Advances in Chemistry Series, 189, American Chemical Society, pp. 73-96.

Thomas, J.E., Jones, C.F., Skinner, W.M., Smart, R.S.C., 1998. The role of surface sulfur species in the inhibition of pyrrhotite dissolution in acid solutions. Geochim. Cosmochim. Acta 62, 1555-1565.

Thomas, J.E., Skinner, W.M., Smart, R.S.C., 2001. A mechanism to explain sudden changes in rates and products for pyrrhotite dissolution in acid solution. Geochim. Cosmochim. Acta 65, 1-12

Wang H., Salveson, I., 2005. A review on the mineral chemistry of the non-stoichiometric iron sulphide, Fe1-xS $(0 \leq x \leq 0.125)$ : polymorphs, phase relations and transitions, electronic and magnetic structures. Phase Transit. 78, 547-567.

Wunderly, M.D., Blowes, D.W., Frind, E.O., Ptacek, C.J., 1996. Sulfide mineral oxidation and subsequent reactive transport of oxidation products in mine tailings impoundments: A numerical model. Water Resour. Res. 32, 3173-3187.

Yakhontova, L.K., Nesterovich, L.G., Grudev, A.P., 1983. New data on natural oxidation of pyrrhotite. Vestnik Moskovskogo Universiteta Geologiya 38, 41-44. 


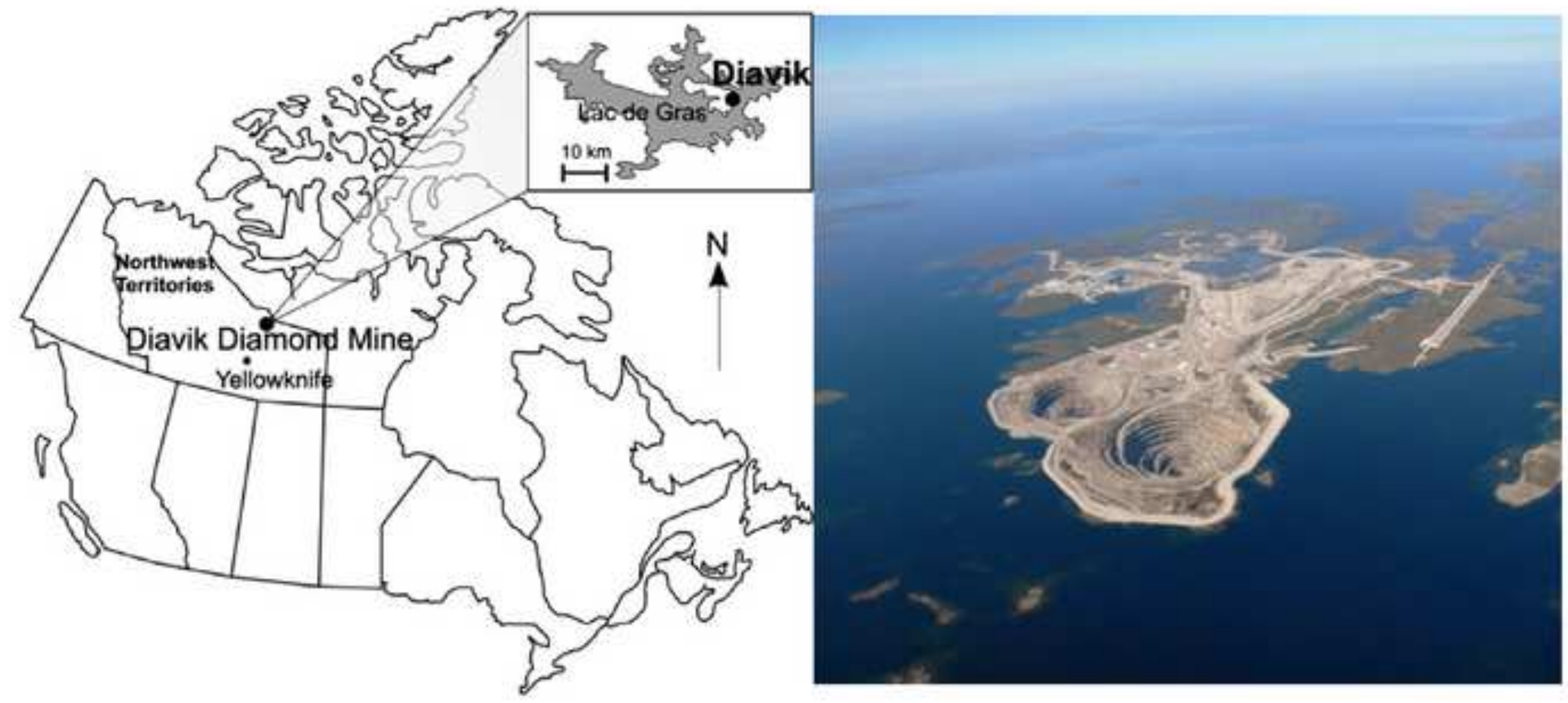



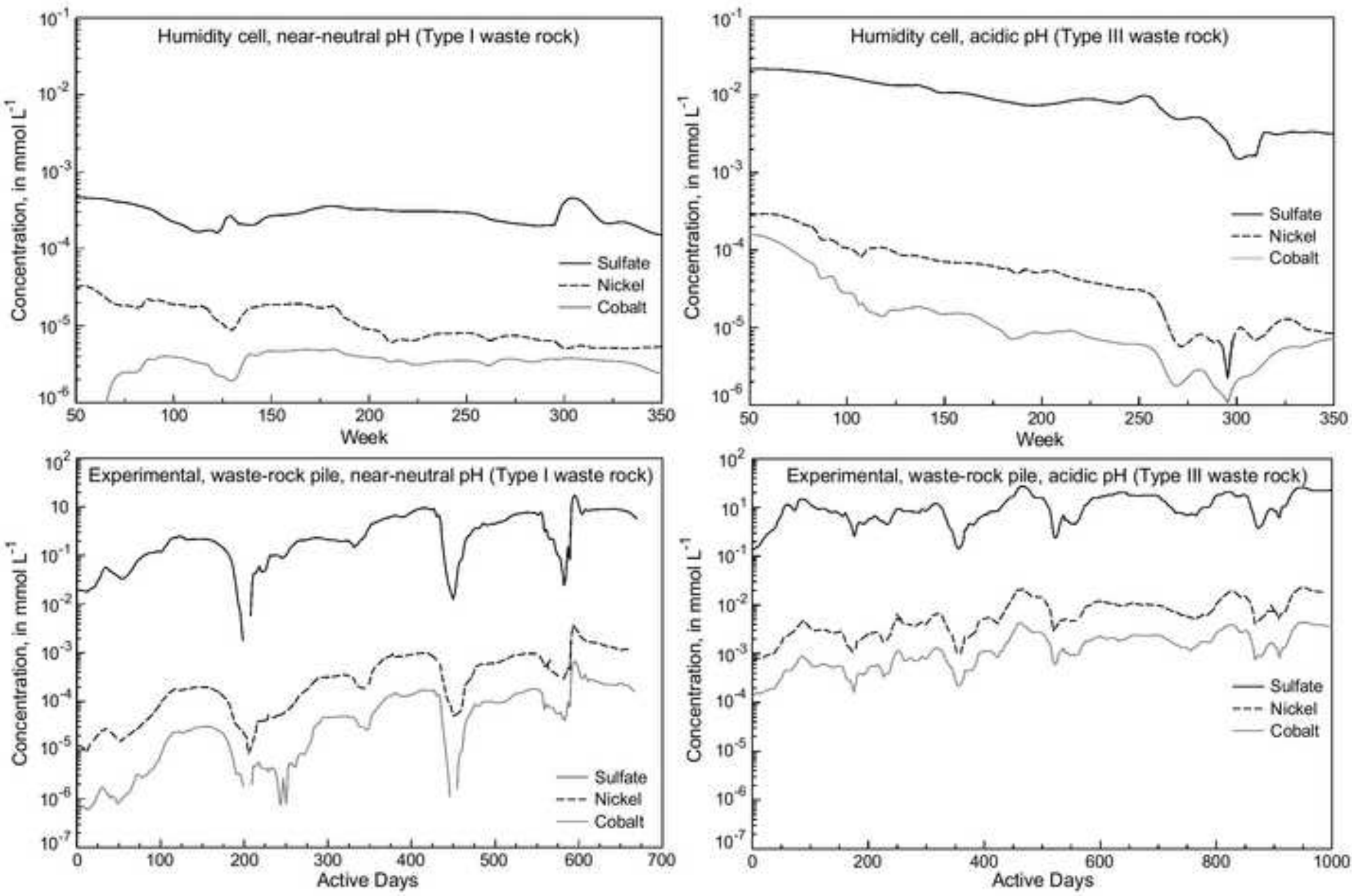


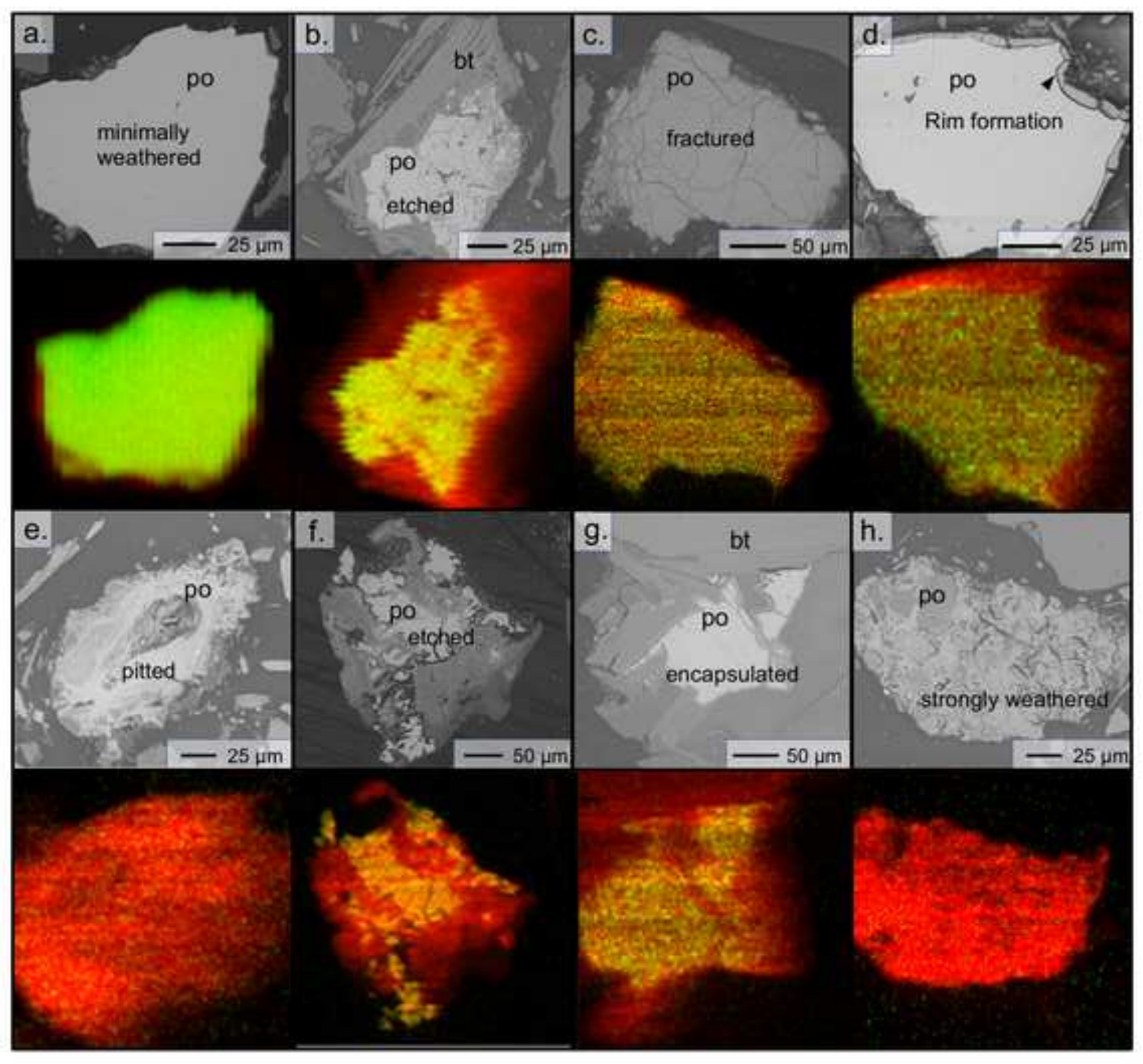




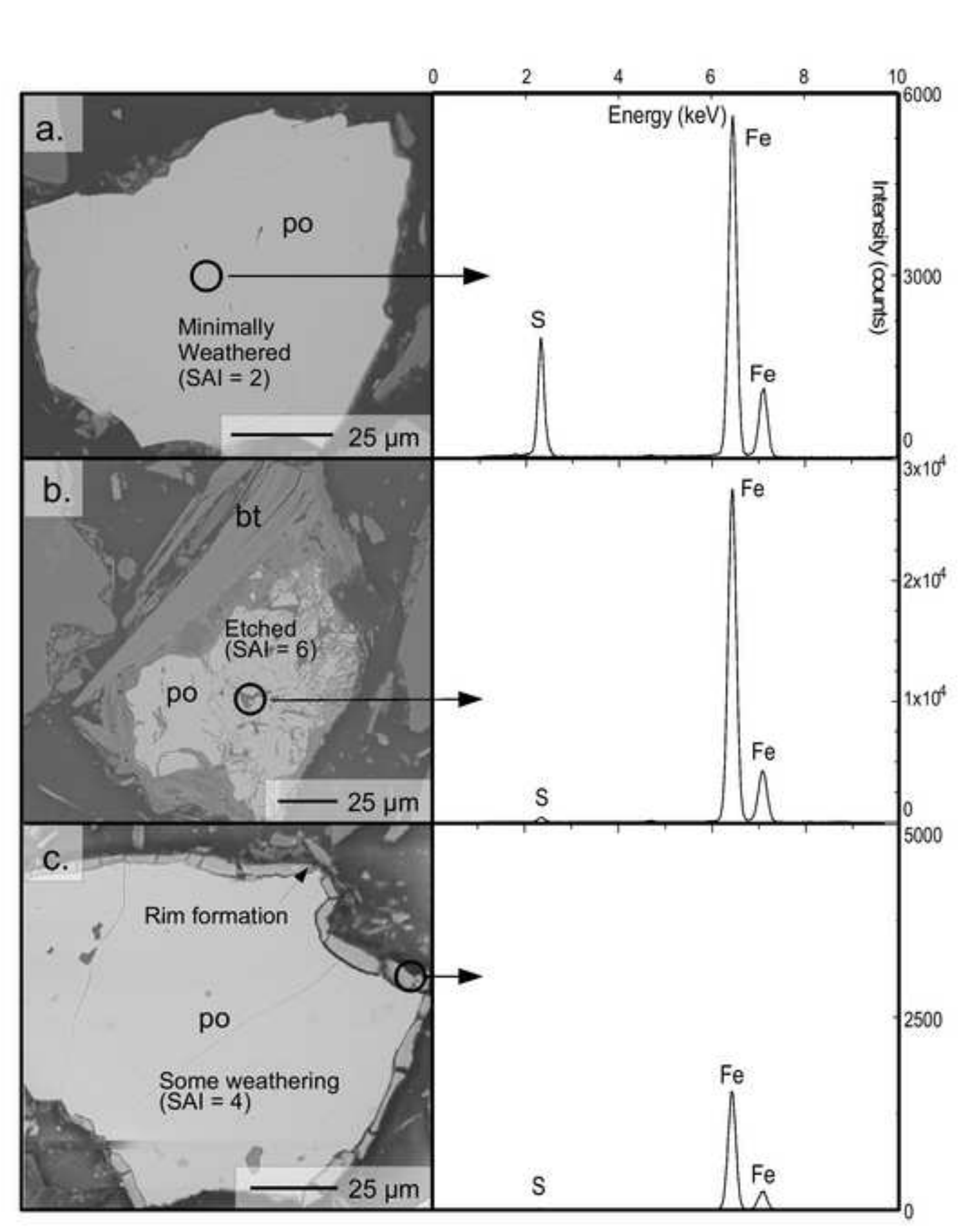

Figure

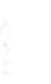

.

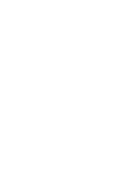

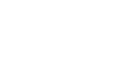




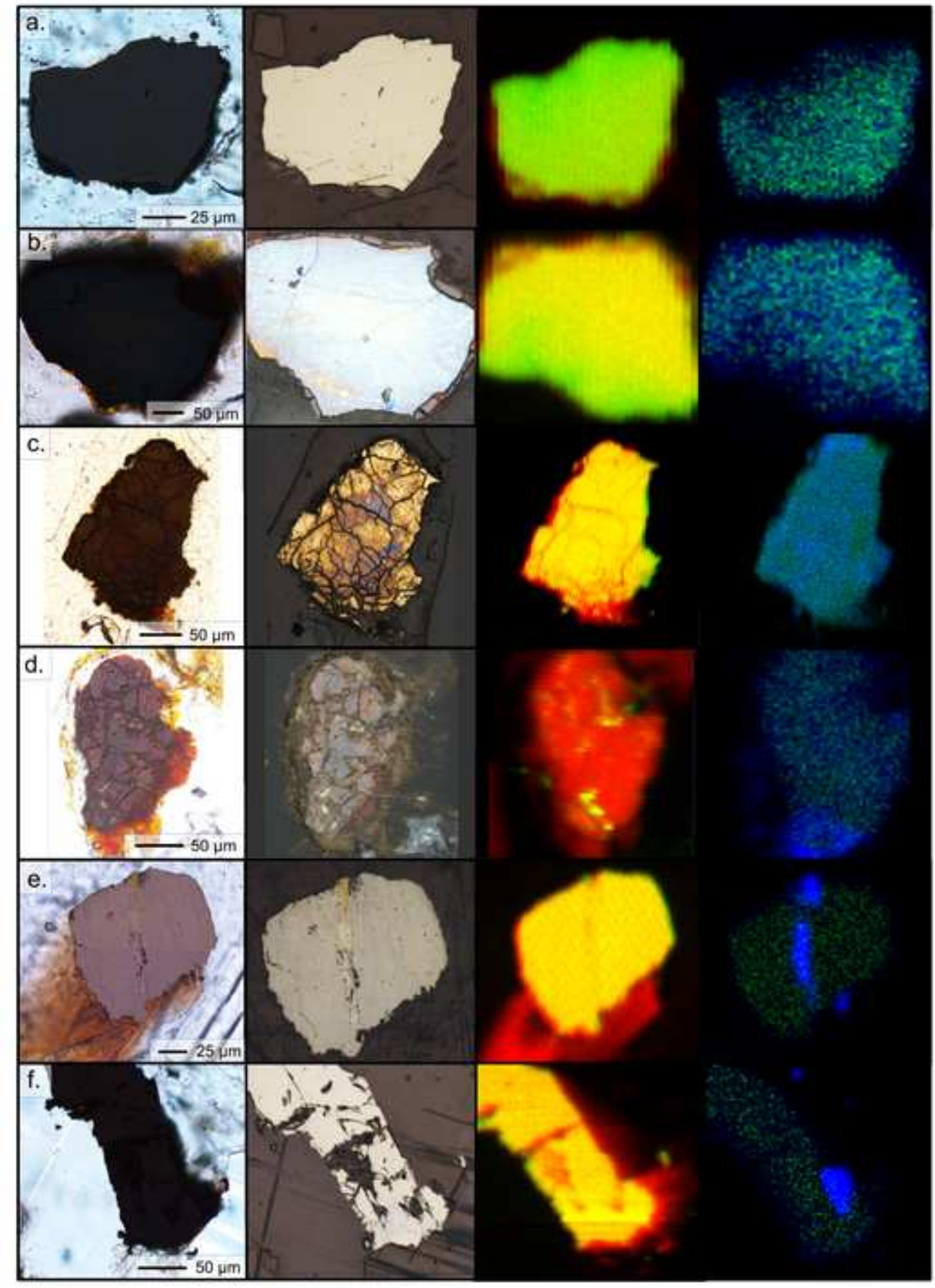

Figure 6

\section{Figure 6}

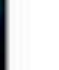

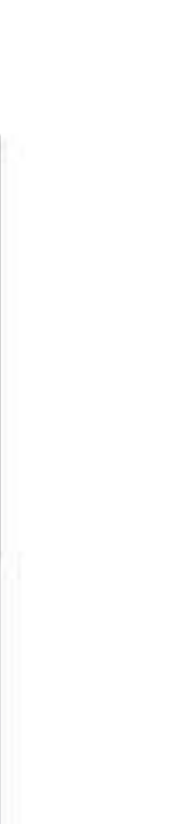

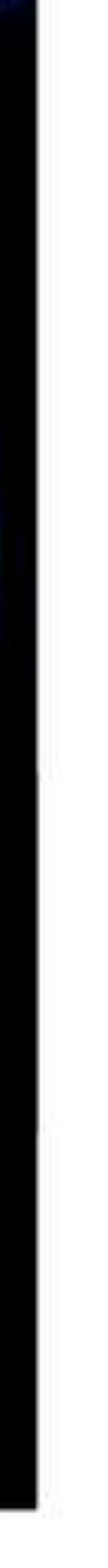

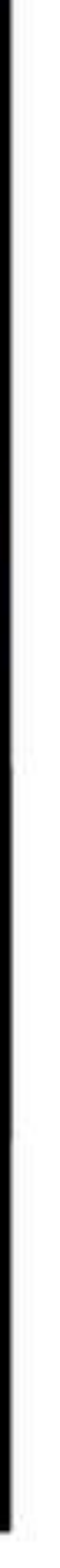



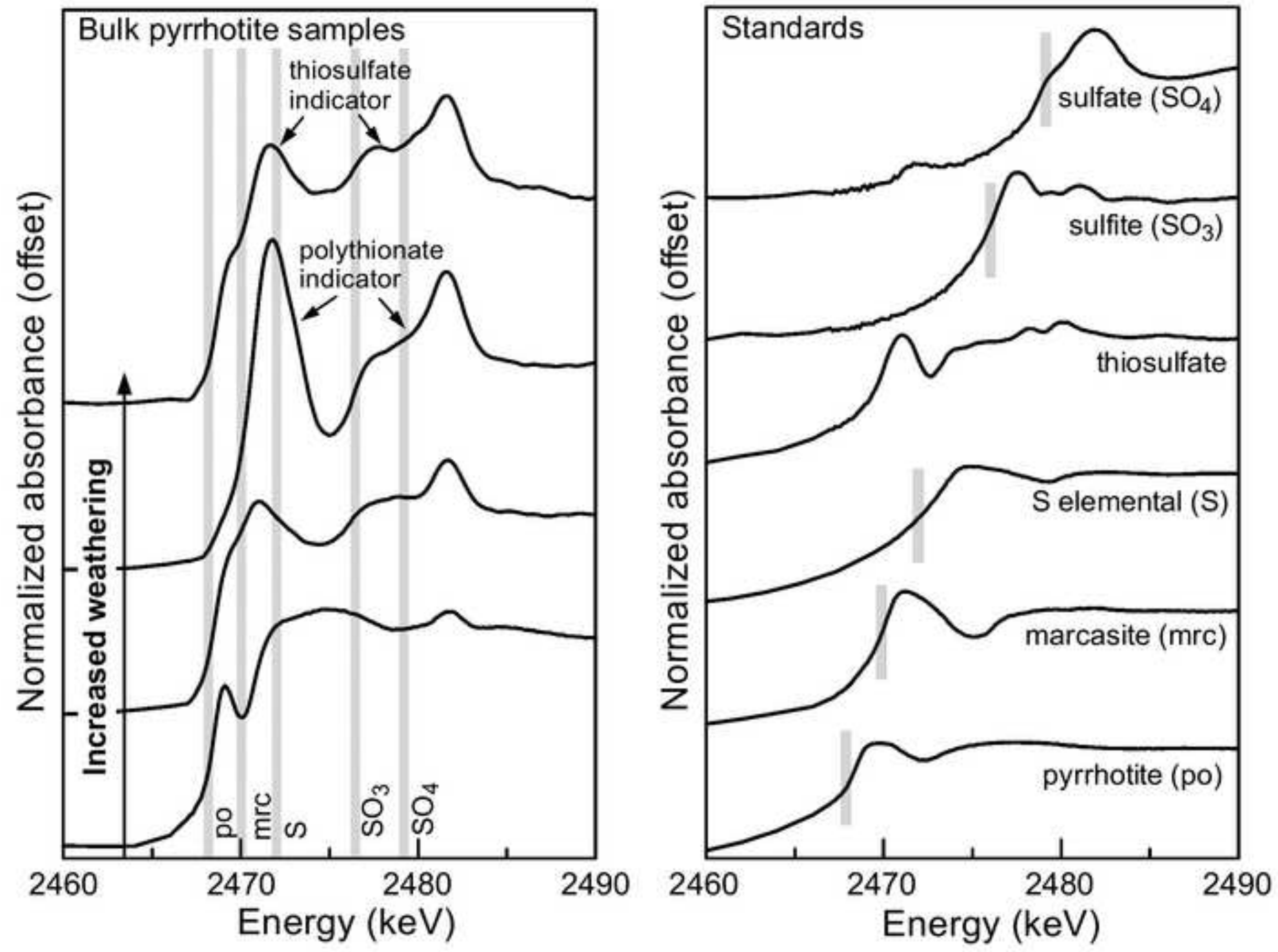


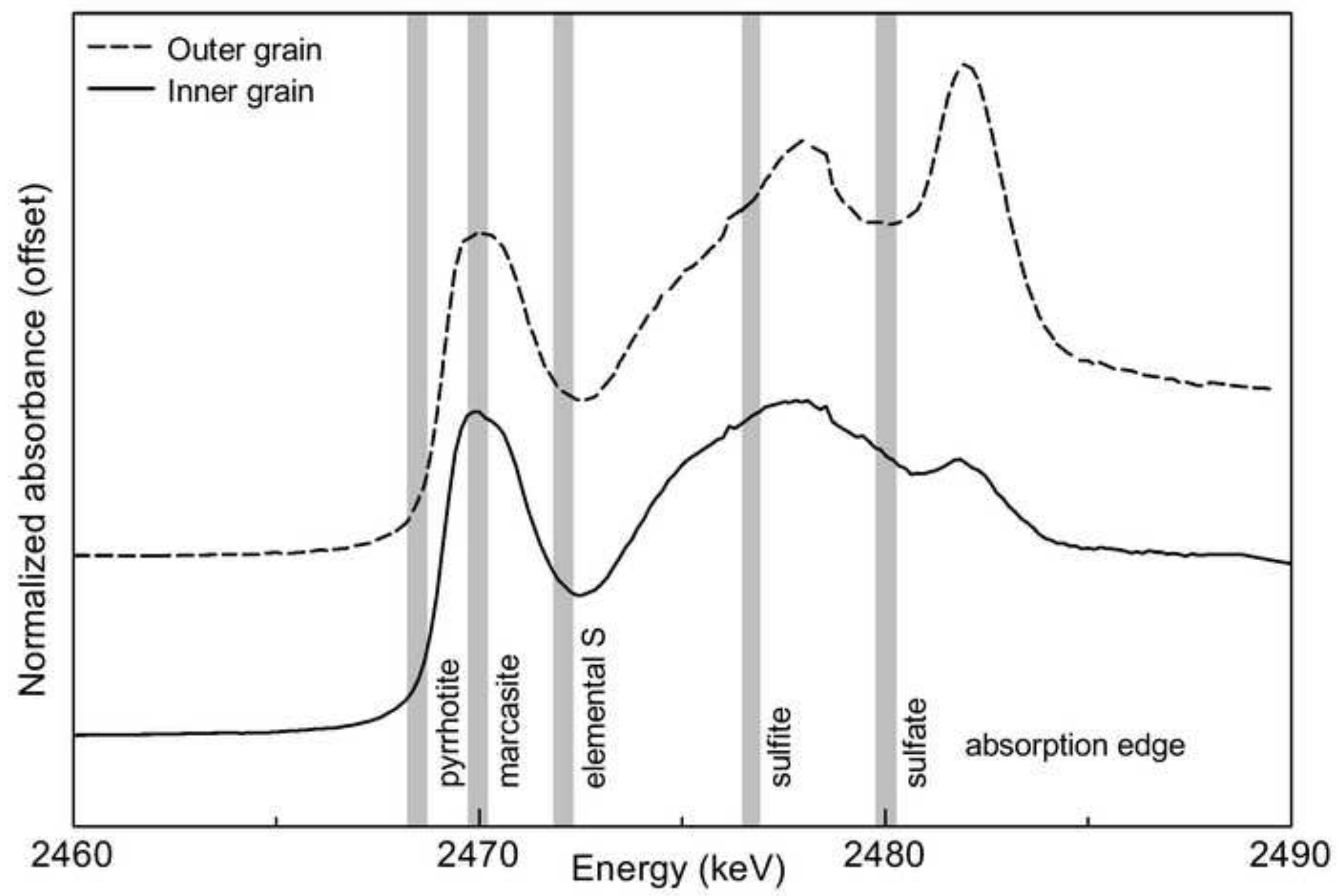




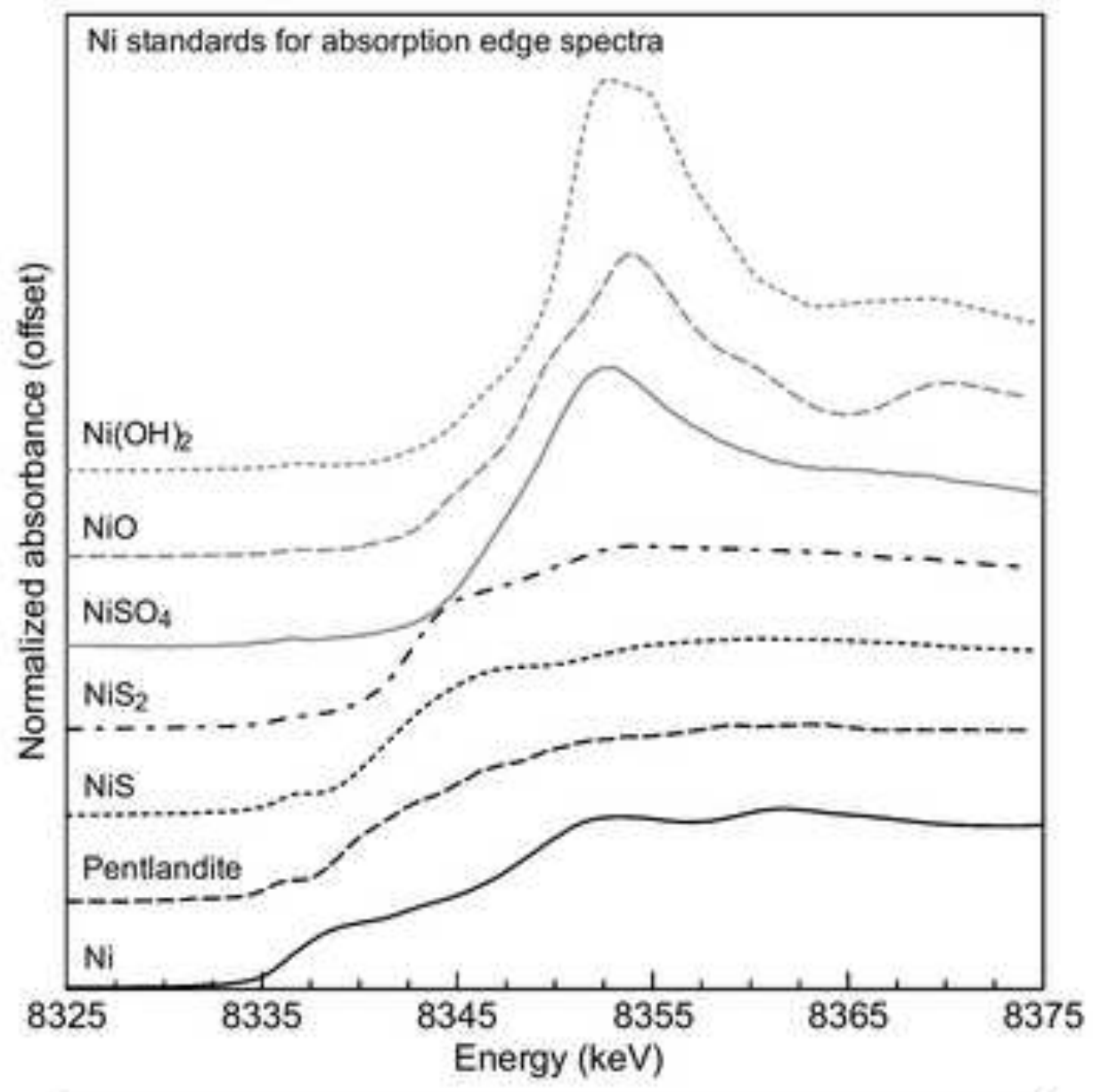

a) Weathered pyrrhotite with distributed Ni (Fig. 6d)

b) Weathered pyrrhotite with pentlandite lamella (Fig. 6e)

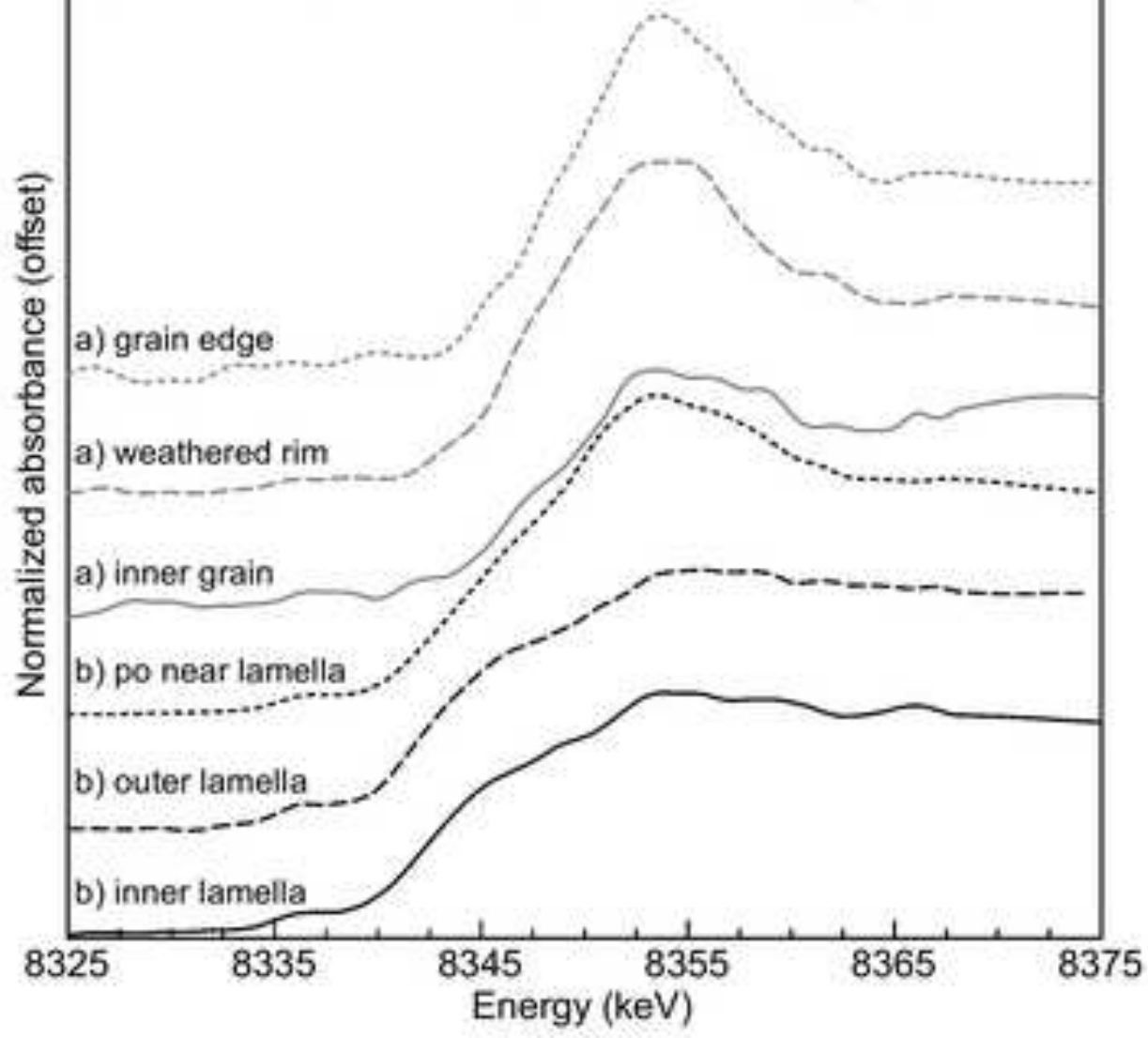

